Published in final edited form as:

Curr Top Microbiol Immunol. 2017 ; 400: 277-304. doi:10.1007/978-3-319-50520-6_12.

\title{
Pathogenesis of gastric cancer: genetics and molecular classification
}

\author{
Ceu Figueiredo ${ }^{1,2,3}$, M. Constanza Camargo ${ }^{4}$, Marina Leite ${ }^{1,2}$, Ezequiel M. Fuentes- \\ Pananá $^{\text {, }}$ Charles S. Rabkin ${ }^{4}$, José C. Machado ${ }^{1,2,3}$ \\ ${ }^{1}$ i3S - Instituto de Investigação e Inovação em Saúde, Universidade do Porto, Porto, Portugal \\ ${ }^{2}$ Institute of Molecular Pathology and Immunology of the University of Porto (Ipatimup), Porto, \\ Portugal \\ ${ }^{3}$ Faculty of Medicine of the University of Porto; Porto, Portugal \\ ${ }^{4}$ Division of Cancer Epidemiology and Genetics, National Cancer Institute, Rockville, Maryland, \\ USA \\ ${ }^{5}$ Research Unit of Cancer and Virology, Children's Hospital of Mexico "Federico Gomez" Mexico \\ City, Mexico.
}

\section{Abstract}

Gastric cancer is the fifth most incident and the third most common cause of cancer-related death in the world. Infection with Helicobacter pylori is the major risk factor for this disease. Gastric cancer is the final outcome of a cascade of events that takes decades to occur and results from the accumulation of multiple genetic and epigenetic alterations. These changes are crucial for tumor cells to expedite and sustain the array of pathways involved in cancer development, such as cell cycle, DNA repair, metabolism, cell-to-cell and cell-to-matrix interactions, apoptosis, angiogenesis and immune surveillance. Comprehensive molecular analyses of gastric cancer have disclosed the complex heterogeneity of this disease. In particular, these analyses have confirmed that Epstein Barr virus (EBV)-positive gastric cancer is a distinct entity. The identification of gastric cancer subtypes characterized by recognizable molecular profiles may pave the way for a more personalized clinical management and to the identification of novel therapeutic targets and biomarkers for screening, prognosis, prediction of response to treatment, and monitoring of gastric cancer progression.

\section{Keywords}

Gastric cancer; Helicobacter pylori ; Epstein Barr virus; chromosomal instability; microsatellite instability; hereditary gastric cancer

Correspondence to: Jose C. Machado, PhD, Ipatimup, Rua Júlio Amaral de Carvalho 45, 4200-135 Porto, Portugal. Tel. +351-22-5570700; Fax: +351-22-5570799, josem@ipatimup.pt. 


\section{Gastric cancer epidemiology}

Gastric cancer is the fifth most incident malignancy in the world, with 952,000 new cases (6.8\% of the total number of cancers) estimated to have occurred in 2012 (Ferlay et al. 2013). Of these, 823,000 cases were at non-cardia anatomic subsites. The incidence greatly varies between countries and the majority of cases are registered in developing countries, half of them occurring in Eastern Asia. Gastric cancer incidence is twice as high in men than in women, suggesting that environmental, hormonal, and/or genetic exposures may affect risk.

Globally, gastric cancer is the third most common cause of death by cancer, representing 723,000 deaths (8.8\% of all cancer deaths) in 2012 (Ferlay et al. 2013). The mortality rate is quite similar to the incidence rate with the highest estimated mortality rates observed in Eastern Asia. The high mortality rates of gastric cancer are due to the paucity of clinical symptoms, consequent late diagnosis, absence of screening, and ineffective treatments. Thus, the majority of patients present advanced-stage tumors at the point of diagnosis. The five-year survival of gastric cancer patients of all stages is about $25 \%$ and the median overall survival is less than one year (Gastric Group et al. 2013).

Gastric cancer incidence and mortality have been declining over the past decades, and this has been related to a decrease in the prevalence of Helicobacter pylori, probably as a result of improved living conditions, hygiene and sanitation, as well as to the widespread use of antimicrobials (Ferro et al. 2014). Nevertheless, and despite the declining rates, the global burden of gastric cancer is expected to increase in the coming years due to the demographic effects of growth and ageing of the population worldwide (Ferlay et al. 2013).

\section{Histological phenotypes of gastric cancer}

From the morphologic standpoint, gastric cancer is very heterogeneous, which is reflected by the diversity of histopathological classifications (Carneiro et al. 1995; Lauren 1965; Ming 1977; Lauwers et al. 2010). The most widely used classification was proposed by Lauren, in which gastric cancer is divided in two main types - intestinal and diffuse - which also differ from each other clinically and epidemiologically (Lauren 1965). Intestinal-type tumors are usually exophytic, often ulcerating, and are associated with intestinal metaplasia of the stomach. Diffuse-type tumors are poorly differentiated infiltrating lesions, which lead to thickening of the stomach (linitis plastica). Patients with diffuse-type tumors appear to have a worse prognosis than those with intestinal-type tumors. Intestinal-type cancers are more common in proximal (fundus) location while diffuse-type tumors predominate in younger patients (Lo et al. 1996). Interestingly, diffuse-type tumors demonstrate a nearly equal sex ratio, compared with the male preponderance in the intestinal-type.

Correa proposed a model of gastric carcinogenesis according to which the intestinal-type carcinoma represents the end-product of a cascade of sequential changes in gastric mucosa including superficial gastritis, chronic atrophic gastritis, small intestinal metaplasia, colonic metaplasia and adenomatous (flat or polypoid) dysplasia (Correa 1988, 1992). The sequence of histogenetic changes leading to diffuse-type cancer is less well-defined. A further 
complication for these models of precancerous stages is that a substantial fraction of gastric cancers are characterized by the co-existence of both intestinal-type and diffuse-type morphologic features (Carneiro et al. 1995).

\section{Helicobacter pylori infection and gastric cancer}

Helicobacter pylori infection is the major risk factor for gastric cancer and has been considered as a Group 1 carcinogen by the International Agency for Research on Cancer (IARC 1994). A reevaluation incorporating a substantial amount of new available data provided support for an association between $H$. pylori infection and non-cardia gastric cancer (IARC 2011). Recent estimates show that $89 \%$ of all non-cardia tumors (about 780,000 cases) is attributable to $H$. pylori infection, making this bacterium responsible for at least $6.2 \%$ of all cancer cases worldwide (Plummer et al. 2015). It must be noted, however, that the detection methods may not be sensitive enough and that the true fraction of attributable cases may actually be higher than $89 \%$.

Adding to the geographic overlap between the prevalence of $H$. pylori infection and the incidence of gastric cancer, epidemiological data from cohort studies, case-control studies, and meta-analyses also evidenced the carcinogenicity of chronic H. pylori infection in humans (IARC 2011). Risk estimates from a combined analysis of 12 independent prospective cohort studies showed an association between $H$. pylori seropositivity and noncardia tumors with an overall odds ratio of 2.97 (95\% CI 2.34-3.77), but not with cardia tumors (Helicobacter and Cancer Collaborative Group 2001). The magnitude of the risk is higher, reaching 21-fold, when more sensitive assays are used for determining the $H$. pylori status (Gonzalez et al. 2012; Ekstrom et al. 2001). The risk associated with infection with CagA-positive H. pylori strains is also higher than that of infection with CagA-negative strains (Huang et al. 2003; Kamangar et al. 2006; Palli et al. 2007). Moreover, H. pylori eradication reduces the incidence of gastric cancer. In a meta-analysis of six randomized eradication trials, including 6497 participants, H. pylori eradication was superior to placebo or no treatment in preventing gastric cancer, with a risk ratio of 0.66 (95\% CI 0.46-0.95) (Ford et al. 2015).

Noteworthy, not all of the $H$. pylori-infected individuals will develop gastric cancer, which points to a multifactorial etiology of this disease. Indeed, host genetic susceptibility factors that influence the inflammatory response to the infection and lifestyle factors such as smoking and diet with a high-salt content are associated with increased gastric cancer risk (Figueiredo et al. 2002; Gonzalez et al. 2003; Persson et al. 2011; Peleteiro et al. 2011).

The mechanisms of malignant transformation mediated by $H$. pylori infection are discussed in chapters 2, 8-11 and 13.

\section{Epstein-Barr virus infection and gastric cancer}

Epstein Barr virus (EBV) is almost ubiquitous in the human population, primarily maintained as a latent infection in a subset of B-lymphocytes comprising roughly $0.001 \%$ of peripheral blood mononuclear cells. In vitro, EBV infection of B cells is highly efficient with most B cells becoming immortalized after infection. In B cells, the viral envelope 
glycoprotein gp350 binding to the B-cell surface coreceptor CD21, tethers the virus to the host cell surface and subsequent binding to human leukocyte antigen (HLA) class II facilitates fusion of viral and cell membranes, releasing the viral capsid into the cytoplasm (Fingeroth et al. 1984; Li et al. 1997; Nemerow et al. 1987; Tanner et al. 1987). HLA binding and fusion are mediated by a different set of envelope glycoproteins: $\mathrm{gH}, \mathrm{gL}$, gp42 and gB (the fusion core complex) (Hutt-Fletcher 2007). gp42 is the main HLA class II-binding protein bridging between a $\mathrm{gH} / \mathrm{gL}$ heterodimer and HLA. $\mathrm{gH} / \mathrm{gL}$ binds $\mathrm{gB}$, the main effector of viral fusion (Backovic et al. 2007a; Backovic et al. 2007b).

On the other hand, epithelial cells are nearly refractory to EBV and susceptibility to infection is facilitated only under special experimental conditions, e.g. after ectopic expression of CD21 or after B cell-mediated transference of viral particles (Borza et al. 2004; Shannon-Lowe et al. 2006; Shannon-Lowe and Rowe 2011). In epithelial cells EBV entry is thought to be mediated by integrins. Several interactions have been described, including $\mathrm{gH} / \mathrm{gL}$ with the integrin receptors $\operatorname{av} \beta 5$, av $\beta 6$ and $\operatorname{av} \beta 8$, and the viral envelope glycoprotein BMRF2 with the cellular transmembrane receptor integrins av, a3, a5, and $\beta 1$ (Chesnokova et al. 2009; Hutt-Fletcher and Chesnokova 2010; Chesnokova and HuttFletcher 2011; Tugizov et al. 2003; Xiao et al. 2008). Viral fusion also requires binding to the cellular transmembrane glycoprotein neuropilin 1 (Wang et al. 2015).

EBV released by B cells and by epithelial cells bear distinctive envelopes displaying different tropisms. $\mathrm{gH} / \mathrm{gL} / \mathrm{gp} 42$ trimers are enriched in epithelial cell-derived viruses, while gp42 is lacking on virus released by B cells (Chen et al. 2012; Wang et al. 1998). Since gp42 mediates binding to HLA class II, B cell-originated virus has an enhanced tropism for epithelial cells, and epithelial cell-originated virus for B cells. This switching tropism has important implications at an individual level. Integrins are exclusively expressed at the basolateral face of polarized epithelia, the side contacting circulating B cells (Lee and Streuli 2014; Manninen 2015). On the contrary, virus present in saliva contains gp42 exhibiting an enhanced tropism for B cells (Jiang et al. 2006). Thus, persistent infection of epithelia most probably follows virus released by reactivated B cells in chronically infected hosts. Also, epithelial infection is more permissive for IgA- and CD21-bound virus and after formation of B cell-epithelial cell conjugates (Shannon-Lowe et al. 2006; Shannon-Lowe and Rowe 2011; Sixbey and Yao 1992), all mechanisms favored at the basolateral face. All these data support a model of viral transmission in which EBV-infected B cells circulating close to the basolateral side would be reactivated by stimuli that are still not clear, producing viral particles with an increased capacity to infect epithelial cells.

In B cells, viral expression starts with the EBV nuclear antigens (EBNAs), EBNA-LP (leader protein), EBNA-2, EBNA-1, the EBNA-3 family ( $-3 a,-3 b$ and $3 c$ ) and the latent membrane proteins (LMP), LMP1, LMP-2A and LMP-2B (the latency III program). In vivo, EBV switches between different gene expression programs (latencies), presumably to counteract immune cell responses. In immune-competent hosts the germinal center model argues that infection guides the B cell into a series of stages that mimic antigen-activation and formation of long-lived memory B cells (Thorley-Lawson et al. 2013). While passing through the germinal center, viral gene expression is reduced to EBNA-1, LMP1 and LMP2A (latency II), EBNA-1 only (latency I) and no protein expression (latency 0). Latency 
0 is found in memory cells and is considered the ultimate state of EBV persistence (Babcock et al. 2000). During these latency programs, EBV also expresses several untranslated RNAs: the EBER-1 and EBER-2 (EBV encoded small RNAs), and about 25 pre-microRNAs (premiRNAs). Expression of EBNA-1, LMP2A and non-coding RNAs with or without LMP1 has been demonstrated in epithelial cells in vitro and in vivo.

EBV is considered to be a human carcinogen linked to development of several types of lymphoma and carcinoma, accounting for about 200,000 new cancer cases annually worldwide. In particular, this virus was first detected (via polymerase chain reaction) in a gastric tumor in 1990 (Burke et al. 1990). Approximately 9\% of gastric cancer caseshave latent EBV infection in every tumor cell (Murphy et al. 2009). This fraction is relatively constant in both high- and low-gastric cancer incidence populations worldwide. Consequently, EBV-related gastric cancer is the most common malignancy associated with EBV infection, exceeding even EBV-related nasopharyngeal carcinoma in number of cases annually (Cohen et al. 2011).

Since EBV infection is so common in humans, presence of the virus in tumor tissue is needed to implicate the infection in gastric carcinogenesis. However, the tissue inflammation often present in gastric cancer may lead to infiltration of incidental EBV-infected leukocytes as a non-specific source. Conventionally, EBV is localized to tumor cells by in situ hybridization for the abundant EBER-1 and -2 transcripts of unknown function. Nextgeneration sequencing provides a versatile alternative for identification of EBV-positive tumors (Camargo et al. 2016a). In viral-positive tumors, the nucleic acids are present as circularized episomes and chromosomal integration does not appear to occur. The episomes are monoclonal with uniform terminal repeats in a given tumor, indicating infection was present at the time of transformation in the clonal progenitor cell.

EBV-infected lymphocytes in inflamed gastric mucosa may represent the route of introduction into the gastric epithelium (Ryan et al. 2012). Nevertheless, studies are inconsistent about the presence of EBV in epithelial cells of premalignant lesions, including intestinal metaplasia and dysplasia (Gulley et al. 1996). In prospective follow-up of a high-risk population, serologic markers of viral reactivation were associated with gastric pre-neoplastic lesions and risk of progression (Schetter et al. 2008).

EBV genome sequences vary among isolates, with two recognized major types based primarily on variation of EBNA-2 and EBNA-3 genes (Palser et al. 2015). Furthermore, some strains have greater propensity for infecting epithelial cells, which may be indicative of carcinogenic competence (Tsai et al. 2013). However, there is no known association to date of particular viral genotypes with EBV-positive gastric cancer.

EBV reactivation from latency is a postulated mechanism for the development of EBV-associated malignancies. Supporting this hypothesis, serologic studies have found significantly higher immunoglobulin $\mathrm{G}$ antibody titers against the viral capsid and early antigens (although not against EBNA) in patients with EBV-positive tumors as compared to EBV-negative cases (Levine et al. 1995; Shinkura et al. 2000). 
There is limited evidence on the possible interaction or antagonism between EBV and $H$. pylori in gastric carcinogenesis. In a study comparing $H$. pylori serologic profiles of patients with EBV-positive and -negative non-cardia tumors, antibody levels to $15 \mathrm{H}$. pylori proteins did not vary by tumor EBV status (Camargo et al. 2016b). This similarity of host-response indicates that $H$. pylori plays an essential role in the etiology of EBV-positive tumors as well.

Taken together, much has been learned about EBV-positive gastric cancer since it was first documented, but important knowledge gaps remain. It is still unclear when and how the virus appears in the gastric epithelium prior to tumor emergence. Elucidating the viral contribution to gastric cancer pathophysiology could lead to novel strategies for prevention and treatment, with possible extension to other EBV-related malignancies.

\section{Molecular phenotypes of sporadic gastric cancer}

It has long been recognized that gastric cancer, like other cancers, harbors genetic and epigenetic alterations that contribute to cancer development, progression, and response to therapy (Peltomaki 2012). Previous to the genome-wide characterization of gastric cancer, several molecular phenotypes, chromosome instability (CIN), microsatellite instability (MSI), CpG island methylator phenotype (CIMP), and stable or diploid tumors, were already described and widely accepted (Ottini et al. 2006). The advent of high-throughput genome-, transcriptome- and proteome-wide approaches, confirmed the remarkable genetic and epigenetic intertumoral heterogeneity of gastric cancer and highlighted the molecular complexity of this disease.

Profiling of gastric tumors also led to the emergence of several molecular classification schemes. Gene expression profiling has been used for the discovery of subtypes that may predict patient survival and response to therapeutic modalities. Unsupervised hierarchical clustering analysis of data obtained with cell lines identified two major gastric cancer subtypes with distinct genomic signatures: one associated with intestinal tumors and enriched in biological functions related to carbohydrate and protein metabolism and cell adhesion, designated G-INT; and one associated with diffuse tumors and enriched in cell proliferation and fatty acid metabolism functions, designated G-DIF, (Tan et al. 2011). Although related with Lauren's histotypes, the overall concordance was only $64 \%$, and thus G-INT and G-DIF molecular subtypes were considered distinct. In fact, and unlike Lauren's classification, the G-INT and G-DIF gene expression patterns were prognostic of survival in various patient cohorts, and patients with G-DIF gastric cancer had worse survival outcomes. Furthermore, distinct in vitro sensitivities of G-INT cell lines to chemotherapeutic agents 5fluorouracil and oxaliplatin and of G-DIF cell lines to cisplatin were observed, and patients with G-INT tumors benefited from adjuvant 5-fluorouracil based therapy.

Following this early discovery study, gene expression profiling of gastric tumors led to the identification of proliferative, metabolic, and mesenchymal gastric cancer subtypes (Lei et al. 2013). Proliferative subtype tumors are mostly of the intestinal-type, have high levels of genomic instability with recurrent ERBB2, KRAS, CCNE1, and MYC gene amplification, DNA hypomethylation and high levels of tumor suppressor gene TP53 
mutations. Mesenchymal subtype tumors are mostly of the diffuse-type, contain cells with cancer stem cells features, and are particularly sensitive to inhibitors of the PI3KAKT-mTOR kinase pathway. Metabolic subtype tumors include both diffuse and intestinal histological types and show high expression of genes associated with metabolic pathways as well as features of spasmolytic polypeptide-expressing metaplasia (SPEM). Metabolic subtype tumor cells were sensitive to 5-fluorouracil in vitro, which concurred with the findings that metabolic subtype gastric cancer patients from two independent cohorts had benefit from 5-fluorouracil treatment in terms of cancer-specific and disease-free survival. However, there were no major differences in survival among these three gastric cancer subtypes.

A more comprehensive analysis of gastric cancer by The Cancer Genome Atlas (TCGA) network which studied a series of 295 untreated, surgically-resected tumors with array-based somatic copy number analysis, whole-exome sequencing, array-based DNA methylation profiling, mRNA sequencing, microRNA sequencing, and reverse-phase protein array, led to the proposal of four molecular subtypes (Figure 12.1 A): tumors with CIN, tumors with MSI, genomically stable (GS) tumors, and EBV-positive tumors (Cancer Genome Atlas Research 2014). Using this classification, no significant differences in patient survival and tumor recurrence rates were observed between subtypes, but the follow-up time of the cohort was limited at the time of analysis.

The Asian Cancer Research Group (ACRG) used gene expression data to define four gastric cancer molecular subtypes that were linked to distinct patterns of molecular alterations, disease progression and prognosis (Figure $12.1 \mathrm{~B}$ ): the epithelial to mesenchymal transition (EMT)/microsatellite stable (MSS) subtype, the MSI subtype, the MSS/TP53+ and the MSS/TP53-, the last two based on the status of TP53 activation (Cristescu et al. 2015). EMT/MSS tumors are mainly of the diffuse type, occur at an earlier age, and patients have the worst prognosis and the highest recurrence rate of the four subtypes. MSI tumors are hypermutated, occur frequently in the antrum, are mostly of the intestinal histotype, and patients have the best overall prognosis and the lowest recurrence rate. Patients with MSS/TP53+ and MSS/TP53- tumors have intermediate prognosis and recurrence rates, the former showing better prognosis. EBV infection occurred more frequently in the MSS/ TP53+ subtype. For the sake of an easier correspondence with the classical gastric cancer phenotypes, we will now refer to a more thorough discussion of each of the phenotypes: gastric cancer with CIN, gastric cancer with MSI, genomically stable gastric cancer and EBV-positive gastric cancer.

\subsection{Tumors with chromosomal instability}

$\mathrm{CIN}$ is one of the major genomic instability pathways involved in gastric carcinogenesis, characterized by losses or gains of whole chromosomes resulting in altered chromosome copy number (aneuploidy). CIN may also involve changes in portions of chromosomes, which include allelic losses (LOH), gene deletions and/or amplifications (Lengauer et al. 1998; Ottini et al. 2006).

In the TCGA series, CIN subtype tumors represent about $50 \%$ of the gastric cancers and are localized mainly in the gastroesophageal junction/cardia (Cancer Genome Atlas Research 
2014). These tumors have marked aneuploidy and harbor a very high frequency of TP53 mutations $(71 \%)$. CIN subtype tumors frequently harbor gene amplifications.

One of the major functional groups showing gene amplifications in gastric cancer are receptor tyrosine kinases (RTKs). While ERBB2 (HER2), EGFR, and MET amplifications have long been described in gastric cancer, FGFR 2 has only been detected quite recently (Lemoine et al. 1991; Tsugawa et al. 1993; Hara et al. 1998; Sakakura et al. 1999; Graziano et al. 2011; Zang et al. 2011; Deng et al. 2012; Dulak et al. 2012; Wang et al. 2014; Wong et al. 2014; Cancer Genome Atlas Research 2014).

FGFR2 has been recently described as amplified in about $4 \%$ to $10 \%$ of tumors, with no association with histological type (Deng et al. 2012; Jung et al. 2012; Su et al. 2014). Dysregulation of the FGFR signaling pathway is associated with cancer development and progression, and in preclinical models of gastric cancer amplification of FGFR2 is associated with increased tumor cell proliferation and survival (Xie et al. 2013). A large international multicentric study showed that FGFR 2 amplification is related to poor prognosis in patients with resectable tumors, irrespective of ethnic origin and underlying significant differences in clinicopathological parameters, survival and treatment ( $\mathrm{Su}$ et al. 2014). Importantly, gastric cancer cell lines and patient-derived xenograft models carrying FGFR2 amplification exhibit sensitivity to FGFR inhibitors, thus supporting this type of therapeutic intervention (Deng et al. 2012; Xie et al. 2013).

Interestingly, amplifications in RTK genes appear to be mutually exclusive (Deng et al. 2012; Dulak et al. 2012; Das et al. 2014; Wong et al. 2014). RTK amplification (either of $F G F R 2, E R B B 2, E G F R$, or MET) was a predictor of poor prognosis, but considering each of the RTKs as independent factors, patients with MET-amplified tumors and ERBB2amplified tumors where the ones with the worst prognosis (Deng et al. 2012). After adjustment for tumor stage and grade, $E R B B 2$ amplification had the strongest prognostic impact. ERBB2 amplification and high HER2 immunohistochemical overexpression have already been used as stratification biomarkers for anti-HER2 therapies in gastric cancer (Bang et al. 2010; Satoh et al. 2014).

$K R A S$ amplification has only been recently detected in about $10 \%$ of gastric tumors and appears to be mutually exclusive to RTK gene amplification (Deng et al. 2012; Dulak et al. 2012). Patients with tumors exhibiting $K R A S$ amplification have significantly worse prognosis compared with patients with tumors lacking either $K R A S$ or RTK amplification (Deng et al. 2012).

Overall, amplification in this group of genes is present in around 30\% to $40 \%$ of the gastric cancer cases (Deng et al. 2012; Dulak et al. 2012). Considering that several inhibitors that target components of the RTK/RAS signaling pathways are currently in clinical trials, this subgroup of patients may benefit from stratification based on the presence of these genetic alterations.

Genes that encode transcription factors also exhibit amplification in gastric tumors. $M Y C$ amplification and overexpression in gastric cancer are predictors of poor clinical prognosis, especially in patients that have tumors of the intestinal-type (Kozma et al. 2001; Burbano et 
al. 2006). In addition to $M Y C$ and $G A T A 4$ that were previously shown to be amplified in gastric cancer, more recent studies detected amplifications in GATA6 and KLF5 transcription factors (Weiss et al. 2004; Deng et al. 2012; Dulak et al. 2012; Cancer Genome Atlas Research 2014; Cristescu et al. 2015). KLF5, GATA4 and GATA6 are each amplified in about $10 \%$ of tumors and, although their amplification occurs in an independent pattern, they are co-expressed in gastric cancer, especially of the intestinal-type (Cancer Genome Atlas Research 2014; Chia et al. 2015). Recently, Chia et al. showed that KLF5, GATA4 and GATA6 functionally cooperate to regulate common downstream pathways and to promote gastric tumorigenesis (Chia et al. 2015). Interestingly, they identified hepatocyte nuclear factor-4a (HNF4a) as a direct target of KLF5/GATA4/GATA6. HNF4a is present at high levels in intestinal-type tumors with $K L F 5 / G A T A 4 / G A T A 6$ amplifications, is required for gastric cancer proliferation, and can be targeted by the anti-diabetic drug metformin. These findings forecast a therapeutic opportunity for KLF5/GATA4/GATA6-amplified tumors, which together represent about $30 \%$ of gastric cancer cases.

The octamer transcription factor 1-encoding gene (OCT1) is also recurrently amplified and upregulated in gastric cancer and associated with poor prognosis of patients (Qian et al. 2015). Functionally, $O C T 1$ amplification contributes to ERK/MAPK activation leading to accelerated tumor growth. Interestingly, $O C T 1$ amplification displays mutual exclusivity with amplifications in KRAS and FGFR2 (Qian et al. 2015).

Amplifications in genes encoding cell cycle regulators are also observed in gastric cancer. Amplifications of $C C N E 1$ and $C C N D 1$, which encode cyclin E1 and cyclin D1, are observed, respectively, in 15\% and in 10\% of tumors (Akama et al. 1995; Bizari et al. 2006). $C C N E 1$ amplification is associated with the presence of lymph node metastasis (Akama et al. 1995). CDK6, encoding cyclin dependent kinase 6, is also found amplified in about $15 \%$ of tumors (Isinger-Ekstrand et al. 2010). A recent high-resolution profiling of copy number alterations in a panel of 233 gastric cancers confirmed amplifications in $C C N E 1, C C N D 1$ and $C D K 6$ and, most interestingly, detected a pattern of co-occurrence of amplifications in the same tumor between $C C N E 1$ and ERBB2 (Deng et al. 2012). This pattern of amplification co-occurrence has been previously associated with resistance to anti-HER2 therapies in several cancers (Kim et al. 2014b) and may partially explain the modest efficacy of HER2-directed therapies in gastric cancer (Bang et al. 2010; Satoh et al. 2014).

$V E G F A$ is also reported to be amplified in gastric cancer (Dulak et al. 2012; Andreozzi et al. 2014). VEGFA encodes vascular endothelial growth factor A, a growth factor that contributes to tumor-induced angiogenesis that is a critical step in tumor growth and metastasis (Ellis and Hicklin 2008). This may represent an interesting biomarker candidate for predicting clinical outcome in patients with advanced gastric cancer treated with bevacizumab (Van Cutsem et al. 2012).

In the context of CIN, translocations, amplifications and rearrangements may result in gene fusions. For example, an oncogenic fusion of $C D 44$ and the glutamate transporter $S L C 1 A 2$ gene was identified in a small subset (1\% to $2 \%$ ) of gastric tumors (Tao et al. 2011). Interestingly, silencing of CD44-SLC1A2 sensitized cells to cisplatin, a chemotherapeutic 
agent commonly used in gastric cancer, suggesting that this gene fusion represents a potential drug target.

A novel fusion transcript between dihydrouridine synthase 4-like and B-cell receptorassociated protein 29 (DUS4L-BCAP29) that shows functional tumorigenic potential was also described both in gastric cancer cell lines and tumors (Kim et al. 2014a). Additional rare gene fusions involving AGTRAP-BRAF, ERBB2-CDK12, ERBB2-NEUROD2, SLC34A2-ROS1, SNX2-PRDM6, and MLL3-PRKAG2 have been detected in gastric cancer (Palanisamy et al. 2010; Zang et al. 2011; Lee et al. 2013; Yao et al. 2015). Whether they are functionally relevant or can identify novel subclasses of patients that may clinically benefit from targeted therapies remains to be determined.

\subsection{Tumors with microsatellite instability}

The MSI phenotype results from the accumulation of numerous mutations across the genome in short repetitive sequences called microsatellites, due to a defective DNA mismatch repair (MMR) system (Velho et al. 2014). The MMR system corrects basebase mismatches and insertion/deletion mispairs generated during DNA replication and recombination, to prevent mutations from becoming permanent in dividing cells and thus preserve genomic stability (Li 2008). Epigenetic silencing of $M L H 1$ gene by promoter hypermethylation is the main mechanism leading to MMR deficiency in sporadic gastric cancer, accounting for $75 \%$ to $100 \%$ of the cases (Leung et al. 1999; Pinto et al. 2000; Leite et al. 2011).

Tumors can be classified as MSI with high instability (MSI-H), MSI with low instability (MSI-L), or microsatellite stable (MSS) (Umar et al. 2004). It is still not clear in gastric cancer whether MSI-L and MSS represent separate groups, as both appear to have similar phenotypes (Pinto et al. 2000). For the sake of simplicity, hereafter MSI stands for MSI-H.

Tumors with MSI phenotype represent up to $37 \%$ of all stomach cancer cases and constitute a well-defined subset of tumors (Zhu et al. 2015; Cancer Genome Atlas Research 2014). MSI gastric cancer is characterized by antral tumor location, intestinal histological type, expanding growth pattern, absent or minimal desmoplastic response, abundant lymphoid infiltration, diploid DNA content, female gender, old age at presentation, and better prognosis (dos Santos et al. 1996; Yamamoto et al. 1999; Falchetti et al. 2008). No significant associations were observed between the MSI phenotype and anatomical location, Lauren's classification, and lymphocytic infiltration in the TCGA series (Cancer Genome Atlas Research 2014). Divergent studies regarding the prognostic value of MSI in gastric cancerexist, but two recent meta-analyses confirmed that patients with MSI tumors have better prognosis than those with MSS tumors (Choi et al. 2014; Zhu et al. 2015).

Next-generation sequencing (NGS)-based studies provided a comprehensive view of the mutations present in MSI tumors. MSI gastric cancers are characteristically hypermutated tumors with an estimated mutation rate of 31.6 mutations/megabase $(\mathrm{Mb})$ in comparison to 3.3 mutation/Mb in MSS tumors (Wang et al. 2011). Moreover, MSI tumors also portray a distinctively high $\mathrm{C}$-to-T transition signature compared to other gastric cancer molecular subtypes that have enrichment of the C-to-A transversion signature (Yamamoto et al. 1999; 
Wang et al. 2011; Nagarajan et al. 2012; Liu et al. 2014; Wang et al. 2014; Cancer Genome Atlas Research 2014).

Exome sequencing studies that characterized the mutational repertoire of the MSI gastric cancer subset identified ARID1A, PIK3CA, PTEN, ERBB2, ERBB3, KRAS, RNF43, and TP53, among other genes as significantly mutated (Wang et al. 2011; Zang et al. 2012; Wang et al. 2014; Cancer Genome Atlas Research 2014; Liu et al. 2014; Cristescu et al. 2015).

Somatic inactivating mutations in ARID1A, encoding the AT-rich interactive domaincontaining protein $1 \mathrm{~A}$, are consistently identified more frequently mutated in MSI than in MSS tumors (Wang et al. 2011; Zang et al. 2012; Cancer Genome Atlas Research 2014). The ARID1A mutation spectrum also differs between gastric cancer subtypes and while the great majority of mutations in MSI are frameshift due to insertions or deletions (indels) involving short mononucleotide repeats, in MSS tumors mutations are both indels and single nucleotide variations. The high rate of $A R I D 1 A$ mutations is consistent with a driver gene being targeted by the MSI mechanism, since it was 12- to 61-fold higher than the global background mutation rate of somatic indels at mononucleotide tracts of similar length in MSI tumors (Wang et al. 2011). Reduced or absent ARID1A protein expression is observed in the majority of ARID1A-mutated samples and loss of ARID1A expression is more frequent in MSI than in MSS tumors (Wang et al. 2011; Zang et al. 2012; Abe et al. 2012). While no significant differences in disease-free or overall survival are observed in the MSI subtype with mutated or wildtype ARID1A, in MSS tumors loss of ARID1A expression significantly correlates with worse disease-free and overall survival (Abe et al. 2012). In the MSI subset, mutations in $A R I D 1 A$ are significantly associated with activating PIK3CA mutations, but not with TP53 mutations, suggesting that ARID1A and TP53 mutations drive alternative subsets of gastric cancer (Wang et al. 2011).

In MSI tumors, PIK3CA activating mutations are frequent and are mainly localized in the kinase and helical domains (Cancer Genome Atlas Research 2014) and this may represent a target for PI3K inhibitors.

$R N F 43$, encoding an E3 ubiquitin ligase, was identified as frequently mutated in the MSI gastric cancer setting and was also found frequently mutated in MSI colorectal and endometrial cancers (Giannakis et al. 2014). RNF43 is expressed in Lgr5-positive stem cells and negatively regulates $\mathrm{Wnt} / \beta$-catenin signaling. In the pancreatic tumor model, $R N F 43$ inactivating mutations lead to aberrant Wnt activation. Moreover, in preclinical models, blocking of Wnt inhibited the growth of RNF43-mutant pancreatic tumors in vivo, suggesting the use of $R N F 43$ mutations as a biomarker for patient selection for treatment with Wnt inhibitors (Jiang et al. 2013).

Remarkably, in the TCGA series, analysis of genes mutated within MSI tumors, revealed frequent alterations in major histocompatibility complex class I genes, including $H L A-B$ and $B 2 M$ (Cancer Genome Atlas Research 2014). Mutations affecting B2M and $H L A$ inactivation have been previously associated with the MSI phenotype in gastric cancer (Hirata et al. 2007). In colorectal cancer, $\beta 2$-microglobulin deficiency reduces antigen 
presentation and generates tumor phenotypes that are able to escape immune surveillance (Bernal et al. 2012).

In gastric cancer, and in addition to $M L H 1$, other genes can be silenced by promoter hypermethylation, including for example genes involved in DNA repair, such as $M G M T$, cell-cell and cell-matrix interactions, such as $C D H 1$ and TIMP3, cell cycle regulation, like $C D K N 2 A / P 16 I N K 4 A$, and transcriptional regulation, such as $R U N X 3$ (Qu et al. 2013).

Frequently, MSI tumors shows concurrent hypermethylation in multiple loci and this has been termed as $\mathrm{CpG}$ island methylator phenotype (CIMP). Controversy exists as to the full overlap between the MSI and the CIMP phenotype in gastric cancer (Lee et al. 2004; Zouridis et al. 2012; Moarii et al. 2015). A genome-wide characterization of the DNA methylation events associated with gastric cancer disclosed a subgroup of tumors characterized by a CIMP phenotype, which was associated with widespread hypermethylation, young patient age, and adverse outcome in a disease stage independent manner (Zouridis et al. 2012). Interestingly, it was also observed that cell lines with the CIMP phenotype were sensitive to treatment with 5-Aza-2' -deoxycytidine, a DNA methylation inhibitor. This suggests that pharmaceutical interventions with demethylating drugs towards CIMP gastric cancer may be a possibility.

\subsection{Genomically stable tumors}

According to the TCGA study, GS tumors have an enrichment of the diffuse histological type and are diagnosed at an earlier age. Compared to CIN subtype, GS tumors have a low degree of aneuploidy and lower frequency of TP53 mutations. These tumors frequently harbor alterations in the gene encoding the cell-cell adhesion molecule E-Cadherin ( $\mathrm{CDHI}$ ) and in the gene encoding the small GTPase that regulates cell motility Ras homolog gene family, member A (RHOA) (Corso et al. 2013; Cancer Genome Atlas Research 2014). Mutations in $R H O A$ are almost exclusively found in GS tumors. Accordingly, others have identified $R H O A$ mutations in $14 \%$ to $25 \%$ of diffuse-type but not in intestinal-type tumors (Wang et al. 2014; Kakiuchi et al. 2014). RHOA mutations occur at hotspots that cluster at functional domains that are important to the interaction of RhoA with its effectors. Functional analyses revealed that hotspot mutants had defects in RhoA-mediated signaling which can contribute to the lack of cell adhesion and to the invasive growth pattern of diffuse-type tumors (Wang et al. 2014; Cancer Genome Atlas Research 2014).

Interestingly, recurrent structural genomic alterations that are implicated in dysregulated Rho signaling were also found enriched in the GS subtype. CLDN18-ARHGAP26 and CLDN18-ARHGAP6 gene fusions which juxtapose the tight junction protein claudin 18 with GTPase-activating proteins (GAPs) that are RhoA regulators have been identified (Cancer Genome Atlas Research 2014). Functional analyses showed that the CLDN18$A R H G A P 26$ fusion impairs epithelial integrity by reducing cell-cell and cell-extracellular matrix adhesion and by increasing cell invasion (Yao et al. 2015). CLDN18-ARHGAP fusions were mutually exclusive with $R H O A$ mutations and, within the TCGA GS subtype, RHOA and CLDN18-ARHGAP alterations represent about $30 \%$ of cases. 
In accordance with the aforementioned genetic alterations, integrated pathway analysis revealed that cell adhesion was the most enriched biological pathway in GS subtype tumors (Zang et al. 2012; Cancer Genome Atlas Research 2014).

\subsection{EBV-positive tumors}

EBV-positive tumors differ from other gastric cancer types, exhibiting distinct histopathological and epidemiological features. EBV-positive tumors tend to occur in nonantral anatomic subsites and more frequently exhibit diffuse-type histology; tumor EBVpositivity is 2-fold higher in males and 4-fold higher in post-surgical remnant tumors (Murphy et al. 2009; Lee et al. 2009). Since gastric cancer overall is twice as frequent in men than in women, the 2-fold sex difference in EBV positivity implies that the incidence of EBV-positive tumors is approximately 4 times higher in males than females. This relative protection of females is, as yet, unexplained, but similar sex disparities are apparent in other EBV-associated cancers, including Hodgkin's lymphoma, Burkitt lymphoma and nasopharyngeal carcinoma. Regarding behavioral risk factors, tumor EBV positivity has been associated with cigarette smoking but not with alcohol drinking (Camargo et al. 2014b).

Apart from an etiologic contribution in EBV-positive gastric cancer, viral presence may influence clinical progression. In a large, multi-center series, EBV positivity was associated with $30 \%$ lower mortality adjusted for stage and other confounders (Camargo et al. 2014a). Thus, EBV-positive tumors appears to have a more favorable clinical course than gastric cancer overall.

Based on the comprehensive molecular analysis performed by the TCGA, EBV-positive tumors were characterized by extreme CIMP. Notably, EBV-positive tumors had a higher prevalence of DNA hypermethylation than any other subtypes, showing $C D K N 2 A$ / p16INK $4 A$ promoter hypermethylation, while lacking $M L H 1$ hypermethylation that is otherwise characteristic of MSI-associated CIMP. Additionally, EBV-positive tumors are characterized by frequent PIK3CA and ARIDIA mutations, absence of TP53 mutations, and recurrent amplifications of the chromosome 9 locus containing $J A K 2$, and the immunomodulatory $P D-L 1$, and $P D-L 2$ genes (Cancer Genome Atlas Research 2014; Wang et al. 2011).

PIK3CA mutations were present in $80 \%$ EBV-positive tumors in comparison with $42 \%$ of the MSI tumors, and in the former, mutations were dispersed throughout the gene, contrasting with the preference for the kinase and helical domains in EBV-negative tumors (Cancer Genome Atlas Research 2014).

The viral genes with the highest levels of expression in EBV-positive tumors exhibit a uniform transcription pattern, primarily of sequences encoded in the BamH1A gene region of the genome (Cancer Genome Atlas Research 2014). However, other genes are more variable, with about half of EBV-positive gastric cancers exhibiting moderate expression of BNLF2a, a virally-encoded inhibitor of antigen peptide transport (Strong et al. 2015). Viral transcripts and their protein products represent candidate targets for functional studies to explore mechanisms of viral carcinogenesis. 


\section{Hereditary gastric cancer}

While the great majority of gastric cancers are sporadic, familial aggregation occurs in about $10 \%$ of the cases, and of these, only $1-3 \%$ clearly constitute hereditary forms. Hereditary gastric cancers include syndromes such as hereditary diffuse gastric cancer (HDGC), gastric adenocarcinoma and proximal polyposis of the stomach (GAPPS), and familial intestinal gastric cancer (FIGC). gastric cancer has also been identified as part of the tumor spectrum of other hereditary cancer syndromes like hereditary non-polyposis colorectal cancer (HNPCC), Li-Fraumeni syndrome (LFS), familial adenomatous polyposis (FAP) and Peutz-Jeghers syndrome (PJS). The clinical features, genetics, and pathogenesis of the hereditary gastric cancer syndromes have been reviewed recently (Oliveira et al. 2015).

HDGC is one of the best genetically characterized forms of hereditary gastric cancer. Heterozygous germline $\mathrm{CDH} 1$ (E-Cadherin) mutations, including frameshifts, splice-site, nonsense and missense mutations, as well as large rearrangements, were until recently the only known causative alterations of HDGC, representing up to $40 \%$ of patients belonging to families that fulfill the clinical criteria for HDGC (van der Post et al. 2015).

Efforts conducted to identify alternative causative genes for the remaining HDGC that do not harbor $\mathrm{CDH} 1$ alterations enabled the identification of a germline truncating mutation in the a-1-Catenin (CTNNA1) gene (Majewski et al. 2013). This mutation owing to a two-base deletion in CTNNA1 exon 2, was detected in ten individuals with invasive tumors or intramucosal signet ring cells that were part of a large non- $C D H 1$ HDGC pedigree. Loss of a-1-Catenin expression was observed in tumor cells, along with reduced levels of E-Cadherin, consistent with the prediction that the deletion removes key functional domains of the a-1-Catenin, compromising the binding with $\beta$-Catenin and the formation of the E-Cadherin complex. In another study, two novel germline truncating CTNNA1 mutations, one frameshift and one nonsense, were identified in two individuals of unrelated families out of 144 non- $C D H 1$ HDGC probands (Hansford et al. 2015). Immunohistochemistry of the tumors from the two CTNNA1 mutation-positive patients showed loss of a-1-Catenin expression, suggesting the occurrence of an as yet unidentified second hit event at the CTNNA1 locus. Contrasting with previous findings, E-Cadherin expression was preserved in tumors of CTNNA1 mutation-positive patients. These data support that germline CTNNA1 mutations cause HDGC and strengthen the inclusion of CTNNA1 testing in non- $C D H 1$ HDGC families. Screening of mutations in catenin family member genes in 22 non- $C D H 1$ HDGC families did not reveal mutations in CTNNA1, CTNNB1, or CTNND1 and found two nonsynonymous variants in the $\gamma$-Catenin-encoding gene $J U P$ (Schuetz et al. 2012).

Other pathogenic germline mutations in known gastric cancer-predisposing genes, such as $B R C A 2$ and $S T K 11$, and in other cancer-susceptibility genes, such as PRSS1, PALB2, ATM, $M S R 1$, and $S D H B$ have been identified (Hansford et al. 2015). In other HDGC families, screenings of APC, BRCA1, BRCA2, STK11 and TP53 did not identify novel variants that matched the expected inheritance pattern (Majewski et al. 2013). Thus, their role in HDGC needs further investigation. 
Germline mutations in $M A P 3 K 6$ were also identified upon examination of a large family with a history of familial gastric cancer (FGC) without $\mathrm{CDH} 1$ mutations, with many features of HDGC, but with diversity in clinical presentation and advanced age of onset (Gaston et al. 2014). Four individuals with gastric cancer and five of the 27 currently unaffected relatives harbored a germline truncating (p.P946L) MAP3K6 mutation. A de novo second-hit somatic mutation in MAP3K6 was further detected in tumor DNA from one of the p.P946L carriers. In an additional screening of 115 individuals from unrelated non- $C D H 1$ FGC families, four additional MAP3K6 variants, one truncating and three missense, as well as the p.P946L variant, were identified. Within this cohort, DNA hypermethylation of the MAP3K6 gene was observed as a second-hit in tumor DNA of one affected individual. Taking together these observations with the evidence that MAP3K6 (also known as ASK2 or MEKK6) functions as tumor suppressor gene in vivo and is mutated in primary tumors and gastric cancer cell lines, reinforce the notion that MAP3K6 is a strong susceptibility gene candidate predisposing to FGC (Iriyama et al. 2009; Zang et al. 2011).

Germline mutations in INSR (Insulin receptor), FBXO24 (F-box protein 24), and DOT1L (DOT1-like histone H3K79 methyltransferase) have been identified in three affected members of a family with six cases of diffuse-type gastric cancer in two generations (Donner et al. 2015). Analysis of tumor samples of the three patients did not show LOH in any loci of the variants. These variants and the adjacent regions were screened in an additional 26 gastric cancer patients with a confirmed or suspected family history of DGC, but no other nonsynonymous or additional mutations were identified, warranting further validation of these mutations in other HDGC families.

Regarding GAPPS, germline point mutations in the promoter $1 \mathrm{~B}$ of the $A P C$ gene were recently identified in six families ( $\mathrm{Li}$ et al. 2016). The three points mutations identified were located within a Ying Yang transcription factor $(Y Y I)$ binding motif, which inhibits binding of $Y Y 1$ to the $A P C$ promoter, leading to reduced APC expression. $\mathrm{LOH}$ or somatic APC-truncating mutation second hits were found in the majority of the polyps of the fundic glands that are typical of GAPPS, although in only a small number of cells. This fact led authors to suggest that $A P C$ haploinsufficiency is responsible for the fundic gland polyposis in GAPPS, and the second $A P C$ hit might be the driver of dysplasia. No germline mutations have been identified so far in FIGC.

\section{Concluding Remarks}

The most recent results on the characterization and biology of gastric cancer lent further support to the prevailing concept that this disease is highly heterogeneous. While these findings may help explain the ineffectiveness of a one-size fits all approach to treating this disease, they certainly open the door for a more precise clinical management. Future clinical approaches will certainly take into consideration the specific features of the different subgroups. The prognostic significance of the various gastric cancer types may emerge as more data accumulate. Researchers and clinicians should take advantage of the information provided by these studies to both design and test new targeted therapeutic approaches. 


\section{References}

Abe H, Maeda D, Hino R, Otake Y, Isogai M, Ushiku AS, Matsusaka K, Kunita A, Ushiku T, Uozaki H, Tateishi Y, Hishima T, Iwasaki Y, Ishikawa S, Fukayama M (2012) ARID1A expression loss in gastric cancer: pathway-dependent roles with and without Epstein-Barr virus infection and microsatellite instability. Virchows Archiv : an international journal of pathology 461 (4):367-377. doi:10.1007/s00428-012-1303-2 [PubMed: 22915242]

Akama Y, Yasui W, Yokozaki H, Kuniyasu H, Kitahara K, Ishikawa T, Tahara E (1995) Frequent amplification of the cyclin E gene in human gastric carcinomas. Japanese journal of cancer research : Gann 86 (7):617-621. doi: 10.1111/j.1349-7006.1995.tb02442.x [PubMed: 7559076]

Andreozzi M, Quagliata L, Gsponer JR, Ruiz C, Vuaroqueaux V, Eppenberger-Castori S, Tornillo L, Terracciano LM (2014) VEGFA gene locus analysis across 80 human tumour types reveals gene amplification in several neoplastic entities. Angiogenesis 17 (3):519-527. doi:10.1007/ s10456-013-9396-z [PubMed: 24114200]

Babcock GJ, Hochberg D, Thorley-Lawson AD (2000) The expression pattern of Epstein-Barr virus latent genes in vivo is dependent upon the differentiation stage of the infected B cell. Immunity 13 (4):497-506. doi:10.1016/S1074-7613(00)00049-2 [PubMed: 11070168]

Backovic M, Jardetzky TS, Longnecker R (2007a) Hydrophobic residues that form putative fusion loops of Epstein-Barr virus glycoprotein B are critical for fusion activity. Journal of virology 81 (17):9596-9600. doi:10.1128/JVI.00758-07 [PubMed: 17553877]

Backovic M, Leser GP, Lamb RA, Longnecker R, Jardetzky TS (2007b) Characterization of EBV gB indicates properties of both class I and class II viral fusion proteins. Virology 368 (1):102-113. doi:10.1016/j.virol.2007.06.031 [PubMed: 17655906]

Bang YJ, Van Cutsem E, Feyereislova A, Chung HC, Shen L, Sawaki A, Lordick F, Ohtsu A, Omuro Y, Satoh T, Aprile G, Kulikov E, Hill J, Lehle M, Ruschoff J, Kang YK (2010) Trastuzumab in combination with chemotherapy versus chemotherapy alone for treatment of HER2-positive advanced gastric or gastro-oesophageal junction cancer (ToGA): a phase 3, openlabel, randomised controlled trial. Lancet 376 (9742):687-697. doi:10.1016/s0140-6736(10)61121x [PubMed: 20728210]

Bernal M, Ruiz-Cabello F, Concha A, Paschen A, Garrido F (2012) Implication of the beta2microglobulin gene in the generation of tumor escape phenotypes. Cancer immunology, immunotherapy : CII 61 (9):1359-1371. doi:10.1007/s00262-012-1321-6 [PubMed: 22833104]

Bizari L, Borim AA, Leite KR, Goncalves Fde T, Cury PM, Tajara EH, Silva AE (2006) Alterations of the CCND1 and HER-2/neu (ERBB2) proteins in esophageal and gastric cancers. Cancer genetics and cytogenetics 165 (1):41-50. doi:10.1016/j.cancergencyto.2005.08.031 [PubMed: 16490596]

Borza CM, Morgan AJ, Turk SM, Hutt-Fletcher LM (2004) Use of gHgL for attachment of EpsteinBarr virus to epithelial cells compromises infection. Journal of virology 78 (10):5007-5014. doi: 10.1128/JVI.78.10.5007-5014.2004 [PubMed: 15113881]

Burbano RR, Assumpcao PP, Leal MF, Calcagno DQ, Guimaraes AC, Khayat AS, Takeno SS, Chen ES, De Arruda Cardoso Smith M (2006) C-MYC locus amplification as metastasis predictor in intestinal-type gastric adenocarcinomas: CGH study in Brazil. Anticancer research 26 (4b):29092914. [PubMed: 16886612]

Burke AP, Yen TS, Shekitka KM, Sobin LH (1990) Lymphoepithelial carcinoma of the stomach with Epstein-Barr virus demonstrated by polymerase chain reaction. Modern pathology : an official journal of the United States and Canadian Academy of Pathology, Inc 3 (3):377-380.

Camargo MC, Bowlby R, Chu A, Pedamallu CS, Thorsson V, Elmore S, Mungall AJ, Bass AJ, Gulley ML, Rabkin CS (2016a) Validation and calibration of next-generation sequencing to identify Epstein-Barr virus-positive gastric cancer in The Cancer Genome Atlas. Gastric cancer : official journal of the International Gastric Cancer Association and the Japanese Gastric Cancer Association 19 (2):676-681. doi:10.1007/s10120-015-0508-X

Camargo MC, Kim KM, Matsuo K, Torres J, Liao LM, Morgan DR, Michel A, Waterboer T, Zabaleta J, Dominguez RL, Yatabe Y, Kim S, Rocha-Guevara ER, Lissowska J, Pawlita M, Rabkin CS (2016b) Anti-Helicobacter pylori Antibody Profiles in Epstein-Barr virus (EBV)-Positive and EBV-Negative Gastric Cancer. Helicobacter 21 (2):153-157. doi:10.1111/hel.12249 [PubMed: 26251258] 
Camargo MC, Kim WH, Chiaravalli AM, Kim KM, Corvalan AH, Matsuo K, Yu J, Sung JJ, HerreraGoepfert R, Meneses-Gonzalez F, Kijima Y, Natsugoe S, Liao LM, Lissowska J, Kim S, Hu N, Gonzalez CA, Yatabe Y, Koriyama C, Hewitt SM, Akiba S, Gulley ML, Taylor PR, Rabkin CS (2014a) Improved survival of gastric cancer with tumour Epstein-Barr virus positivity: an international pooled analysis. Gut 63 (2):236-243. doi:10.1136/gutjnl-2013-304531 [PubMed: 23580779]

Camargo MC, Koriyama C, Matsuo K, Kim WH, Herrera-Goepfert R, Liao LM, Eurgast EG, Yu J, Carrasquilla G, Sung JJ, Alvarado-Cabrero I, Lissowska J, Meneses-Gonzalez F, Yatabe Y, Ding T, Hu N, Taylor PR, Morgan DR, Gulley ML, Torres J, Akiba S, Rabkin CS (2014b) Case-case comparison of smoking and alcohol risk associations with Epstein-Barr virus-positive gastric cancer. International journal of cancer Journal international du cancer 134 (4):948-953. doi:10.1002/ijc.28402 [PubMed: 23904115]

Cancer Genome Atlas Research N (2014) Comprehensive molecular characterization of gastric adenocarcinoma. Nature 513 (7517):202-209. doi:10.1038/nature13480 [PubMed: 25079317]

Carneiro F, Seixas M, Sobrinho-Simoes M (1995) New elements for an updated classification of the carcinomas of the stomach. Pathology, research and practice 191 (6):571-584. doi:10.1016/ S0344-0338(11)80878-2

Chen J, Rowe CL, Jardetzky TS, Longnecker R (2012) The KGD motif of Epstein-Barr virus gH/gL is bifunctional, orchestrating infection of B cells and epithelial cells. mBio 3 (1). doi:10.1128/ mBio.00290-11

Chesnokova LS, Hutt-Fletcher LM (2011) Fusion of Epstein-Barr virus with epithelial cells can be triggered by alphavbeta5 in addition to alphavbeta 6 and alphavbeta8, and integrin binding triggers a conformational change in glycoproteins gHgL. Journal of virology 85 (24):1321413223. doi:10.1128/JVI.05580-11 [PubMed: 21957301]

Chesnokova LS, Nishimura SL, Hutt-Fletcher LM (2009) Fusion of epithelial cells by Epstein-Barr virus proteins is triggered by binding of viral glycoproteins $\mathrm{gHgL}$ to integrins alphavbeta6 or alphavbeta8. Proceedings of the National Academy of Sciences of the United States of America 106 (48):20464-20469. doi:10.1073/pnas.0907508106 [PubMed: 19920174]

Chia NY, Deng N, Das K, Huang D, Hu L, Zhu Y, Lim KH, Lee MH, Wu J, Sam XX, Tan GS, Wan WK, Yu W, Gan A, Tan AL, Tay ST, Soo KC, Wong WK, Dominguez LT, Ng HH, Rozen S, Goh LK, Teh BT, Tan P (2015) Regulatory crosstalk between lineage-survival oncogenes KLF5, GATA4 and GATA6 cooperatively promotes gastric cancer development. Gut 64 (5):707-719. doi:10.1136/gutjnl-2013-306596 [PubMed: 25053715]

Choi YY, Bae JM, An JY, Kwon IG, Cho I, Shin HB, Eiji T, Aburahmah M, Kim HI, Cheong JH, Hyung WJ, Noh SH (2014) Is microsatellite instability a prognostic marker in gastric cancer? A systematic review with meta-analysis. Journal of surgical oncology 110 (2):129-135. doi:10.1002/ jso.23618 [PubMed: 24737677]

Cohen JI, Fauci AS, Varmus H, Nabel GJ (2011) Epstein-Barr virus: an important vaccine target for cancer prevention. Science translational medicine 3 (107):107fs 107. doi:10.1126/ scitranslmed.3002878

Correa P (1988) A human model of gastric carcinogenesis. Cancer Res 48 (13):3554-3560 [PubMed: 3288329]

Correa P (1992) Human gastric carcinogenesis: a multistep and multifactorial process--First American Cancer Society Award Lecture on Cancer Epidemiology and Prevention. Cancer Res 52 (24):6735-6740. [PubMed: 1458460]

Corso G, Carvalho J, Marrelli D, Vindigni C, Carvalho B, Seruca R, Roviello F, Oliveira C (2013) Somatic mutations and deletions of the E-cadherin gene predict poor survival of patients with gastric cancer. Journal of clinical oncology : official journal of the American Society of Clinical Oncology 31 (7):868-875. doi:10.1200/jco.2012.44.4612 [PubMed: 23341533]

Cristescu R, Lee J, Nebozhyn M, Kim KM, Ting JC, Wong SS, Liu J, Yue YG, Wang J, Yu K, Ye XS, Do IG, Liu S, Gong L, Fu J, Jin JG, Choi MG, Sohn TS, Lee JH, Bae JM, Kim ST, Park SH, Sohn I, Jung SH, Tan P, Chen R, Hardwick J, Kang WK, Ayers M, Hongyue D, Reinhard C, Loboda A, Kim S, Aggarwal A (2015) Molecular analysis of gastric cancer identifies subtypes associated with distinct clinical outcomes. Nature medicine 21 (5):449-456. doi:10.1038/nm.3850 
Das K, Gunasegaran B, Tan IB, Deng N, Lim KH, Tan P (2014) Mutually exclusive FGFR2, HER2, and KRAS gene amplifications in gastric cancer revealed by multicolour FISH. Cancer letters 353 (2):167-175. doi:10.1016/j.canlet.2014.07.021 [PubMed: 25086186]

Deng N, Goh LK, Wang H, Das K, Tao J, Tan IB, Zhang S, Lee M, Wu J, Lim KH, Lei Z, Goh G, Lim QY, Tan AL, Sin Poh DY, Riahi S, Bell S, Shi MM, Linnartz R, Zhu F, Yeoh KG, Toh HC, Yong WP, Cheong HC, Rha SY, Boussioutas A, Grabsch H, Rozen S, Tan P (2012) A comprehensive survey of genomic alterations in gastric cancer reveals systematic patterns of molecular exclusivity and co-occurrence among distinct therapeutic targets. Gut 61 (5):673-684. doi:10.1136/gutjnl-2011-301839 [PubMed: 22315472]

Donner I, Kiviluoto T, Ristimaki A, Aaltonen LA, Vahteristo P (2015) Exome sequencing reveals three novel candidate predisposition genes for diffuse gastric cancer. Familial cancer. doi:10.1007/ s10689-015-9778-z

dos Santos NR, Seruca R, Constancia M, Seixas M, Sobrinho-Simoes M (1996) Microsatellite instability at multiple loci in gastric carcinoma: clinicopathologic implications and prognosis. Gastroenterology 110 (1):38-44. doi:S0016508596000418 [pii] [PubMed: 8536886]

Dulak AM, Schumacher SE, van Lieshout J, Imamura Y, Fox C, Shim B, Ramos AH, Saksena G, Baca SC, Baselga J, Tabernero J, Barretina J, Enzinger PC, Corso G, Roviello F, Lin L, Bandla S, Luketich JD, Pennathur A, Meyerson M, Ogino S, Shivdasani RA, Beer DG, Godfrey TE, Beroukhim R, Bass AJ (2012) Gastrointestinal adenocarcinomas of the esophagus, stomach, and colon exhibit distinct patterns of genome instability and oncogenesis. Cancer Res 72 (17):43834393. doi:10.1158/0008-5472.can-11-3893 [PubMed: 22751462]

Ekstrom AM, Held M, Hansson LE, Engstrand L, Nyren O (2001) Helicobacter pylori in gastric cancer established by CagA immunoblot as a marker of past infection. Gastroenterology 121 (4):784-791. doi:10.1053/gast.2001.27999 [PubMed: 11606491]

Ellis LM, Hicklin DJ (2008) VEGF-targeted therapy: mechanisms of anti-tumour activity. Nat Rev Cancer 8 (8):579-591. doi:10.1038/nrc2403 [PubMed: 18596824]

Falchetti M, Saieva C, Lupi R, Masala G, Rizzolo P, Zanna I, Ceccarelli K, Sera F, Mariani-Costantini R, Nesi G, Palli D, Ottini L (2008) Gastric cancer with high-level microsatellite instability: target gene mutations, clinicopathologic features, and long-term survival. Human pathology 39 (6):925932. doi:10.1016/j.humpath.2007.10.024 [PubMed: 18440592]

Ferlay J, Soerjomataram I, Ervik M, Dikshit R, Eser S, Mathers C, Rebelo M, Parkin DM, Forman D, Bray F (2013) GLOBOCAN 2012 v1.0, Cancer Incidence and Mortality Worldwide: IARC CancerBase No. 11 [Internet]. Lyon, France: International Agency for Research on Cancer; 2013. Available from: http://globocan.iarc.fr, accessed on 07/05/2016.

Ferro A, Peleteiro B, Malvezzi M, Bosetti C, Bertuccio P, Levi F, Negri E, La Vecchia C, Lunet N (2014) Worldwide trends in gastric cancer mortality (1980-2011), with predictions to 2015, and incidence by subtype. Eur J Cancer 50 (7):1330-1344. doi:10.1016/j.ejca.2014.01.029 [PubMed: 24650579]

Figueiredo C, Machado JC, Pharoah P, Seruca R, Sousa S, Carvalho R, Capelinha AF, Quint W, Caldas C, van Doorn LJ, Carneiro F, Sobrinho-Simoes M (2002) Helicobacter pylori and interleukin 1 genotyping: an opportunity to identify high-risk individuals for gastric carcinoma. Journal of the National Cancer Institute 94 (22):1680-1687. doi:10.1093/jnci/94.22.1680 [PubMed: 12441323]

Fingeroth JD, Weis JJ, Tedder TF, Strominger JL, Biro PA, Fearon DT (1984) Epstein-Barr virus receptor of human B lymphocytes is the $\mathrm{C} 3 \mathrm{~d}$ receptor CR2. Proceedings of the National Academy of Sciences of the United States of America 81 (14):4510-4514. [PubMed: 6087328]

Ford AC, Forman D, Hunt R, Yuan Y, Moayyedi P (2015) Helicobacter pylori eradication for the prevention of gastric neoplasia. The Cochrane database of systematic reviews (7):CD005583. doi:10.1002/14651858.CD005583.pub2 [PubMed: 26198377]

Gaston D, Hansford S, Oliveira C, Nightingale M, Pinheiro H, Macgillivray C, Kaurah P, Rideout AL, Steele P, Soares G, Huang WY, Whitehouse S, Blowers S, LeBlanc MA, Jiang H, Greer W, Samuels ME, Orr A, Fernandez CV, Majewski J, Ludman M, Dyack S, Penney LS, McMaster CR, Huntsman D, Bedard K (2014) Germline mutations in MAP3K6 are associated with familial gastric cancer. PLoS genetics 10 (10):e1004669. doi:10.1371/journal.pgen.1004669 [PubMed: 25340522] 
Gastric Group, Oba K, Paoletti X, Bang YJ, Bleiberg H, Burzykowski T, Fuse N, Michiels S, Morita S, Ohashi Y, Pignon JP, Rougier P, Sakamoto J, Sargent D, Sasako M, Shitara K, Tsuburaya A, Van Cutsem E, Buyse M (2013) Role of chemotherapy for advanced/recurrent gastric cancer: an individual-patient-data meta-analysis. Eur J Cancer 49 (7):1565-1577. doi:10.1016/ j.ejca.2012.12.016 [PubMed: 23352439]

Giannakis M, Hodis E, Jasmine Mu X, Yamauchi M, Rosenbluh J, Cibulskis K, Saksena G, Lawrence MS, Qian ZR, Nishihara R, Van Allen EM, Hahn WC, Gabriel SB, Lander ES, Getz G, Ogino S, Fuchs CS, Garraway LA (2014) RNF43 is frequently mutated in colorectal and endometrial cancers. Nature genetics 46 (12):1264-1266. doi:10.1038/ng.3127 [PubMed: 25344691]

Gonzalez CA, Megraud F, Buissonniere A, Lujan Barroso L, Agudo A, Duell EJ, Boutron-Ruault MC, Clavel-Chapelon F, Palli D, Krogh V, Mattiello A, Tumino R, Sacerdote C, Quiros JR, Sanchez-Cantalejo E, Navarro C, Barricarte A, Dorronsoro M, Khaw KT, Wareham N, Allen NE, Tsilidis KK, Bas Bueno-de-Mesquita H, Jeurnink SM, Numans ME, Peeters PH, Lagiou P, Valanou E, Trichopoulou A, Kaaks R, Lukanova-McGregor A, Bergman MM, Boeing H, Manjer J, Lindkvist B, Stenling R, Hallmans G, Mortensen LM, Overvad K, Olsen A, Tjonneland A, Bakken K, Dumeaux V, Lund E, Jenab M, Romieu I, Michaud D, Mouw T, Carneiro F, Fenge C, Riboli E (2012) Helicobacter pylori infection assessed by ELISA and by immunoblot and noncardia gastric cancer risk in a prospective study: the Eurgast-EPIC project. Annals of oncology : official journal of the European Society for Medical Oncology / ESMO 23 (5):1320-1324. doi:10.1093/annonc/ $\operatorname{mdr} 384$

Gonzalez CA, Pera G, Agudo A, Palli D, Krogh V, Vineis P, Tumino R, Panico S, Berglund G, Siman H, Nyren O, Agren A, Martinez C, Dorronsoro M, Barricarte A, Tormo MJ, Quiros JR, Allen N, Bingham S, Day N, Miller A, Nagel G, Boeing H, Overvad K, Tjonneland A, Bueno-De-Mesquita HB, Boshuizen HC, Peeters P, Numans M, Clavel-Chapelon F, Helen I, Agapitos E, Lund E, Fahey M, Saracci R, Kaaks R, Riboli E (2003) Smoking and the risk of gastric cancer in the European Prospective Investigation Into Cancer and Nutrition (EPIC). International journal of cancer Journal international du cancer 107 (4):629-634. doi:10.1002/ijc.11426 [PubMed: 14520702]

Graziano F, Galluccio N, Lorenzini P, Ruzzo A, Canestrari E, D’Emidio S, Catalano V, Sisti V, Ligorio C, Andreoni F, Rulli E, Di Oto E, Fiorentini G, Zingaretti C, De Nictolis M, Cappuzzo F, Magnani M (2011) Genetic activation of the MET pathway and prognosis of patients with high-risk, radically resected gastric cancer. Journal of clinical oncology : official journal of the American Society of Clinical Oncology 29 (36):4789-4795. doi:10.1200/jco.2011.36.7706 [PubMed: 22042954]

Gulley ML, Pulitzer DR, Eagan PA, Schneider BG (1996) Epstein-Barr virus infection is an early event in gastric carcinogenesis and is independent of bcl-2 expression and p53 accumulation. Human pathology 27 (1):20-27. doi:10.1016/S0046-8177(96)90133-1 [PubMed: 8543306]

Hansford S, Kaurah P, Li-Chang H, Woo M, Senz J, Pinheiro H, Schrader KA, Schaeffer DF, Shumansky K, Zogopoulos G, Santos TA, Claro I, Carvalho J, Nielsen C, Padilla S, Lum A, Talhouk A, Baker-Lange K, Richardson S, Lewis I, Lindor NM, Pennell E, MacMillan A, Fernandez B, Keller G, Lynch H, Shah SP, Guilford P, Gallinger S, Corso G, Roviello F, Caldas C, Oliveira C, Pharoah PD, Huntsman DG (2015) Hereditary Diffuse Gastric Cancer Syndrome: CDH1 Mutations and Beyond. JAMA oncology 1 (1):23-32. doi:10.1001/jamaoncol.2014.168 [PubMed: 26182300]

Hara T, Ooi A, Kobayashi M, Mai M, Yanagihara K, Nakanishi I (1998) Amplification of c-myc, $\mathrm{K}$-sam, and c-met in gastric cancers: detection by fluorescence in situ hybridization. Laboratory investigation; a journal of technical methods and pathology 78 (9):1143-1153 [PubMed: 9759658]

Helicobacter and Cancer Collaborative Group (2001) Gastric cancer and Helicobacter pylori: a combined analysis of 12 case control studies nested within prospective cohorts. Gut 49 (3):347353. doi:10.1136/gut.49.3.347 [PubMed: 11511555]

Hirata T, Yamamoto H, Taniguchi H, Horiuchi S, Oki M, Adachi Y, Imai K, Shinomura Y (2007) Characterization of the immune escape phenotype of human gastric cancers with and without high-frequency microsatellite instability. The Journal of pathology 211 (5):516-523. doi:10.1002/ path.2142 [PubMed: 17318812]

Huang JQ, Zheng GF, Sumanac K, Irvine EJ, Hunt RH (2003) Meta-analysis of the relationship between cagA seropositivity and gastric cancer. Gastroenterology 125 (6):1636-1644 [PubMed: 14724815] 
Hutt-Fletcher LM (2007) Epstein-Barr virus entry. Journal of virology 81 (15):7825-7832. doi:10.1128/JVI.00445-07 [PubMed: 17459936]

Hutt-Fletcher LM, Chesnokova LS (2010) Integrins as triggers of Epstein-Barr virus fusion and epithelial cell infection. Virulence 1 (5):395-398. doi:10.4161/viru.1.5.12546 [PubMed: 21178476]

IARC (1994) Schistosomes, liver flukes and Helicobacter pylori. IARC Working Group on the Evaluation of Carcinogenic Risks to Humans. Lyon, 7-14 6 1994. IARC monographs on the evaluation of carcinogenic risks to humans / World Health Organization, International Agency for Research on Cancer 61:1-241

IARC (2011) IARC. Monographs on the evaluation of carcinogenic risks to humans, volume 100. A review of carcinogen-Part B: biological agents. Lyon: International Agency for Research on Cancer.

Iriyama T, Takeda K, Nakamura H, Morimoto Y, Kuroiwa T, Mizukami J, Umeda T, Noguchi T, Naguro I, Nishitoh H, Saegusa K, Tobiume K, Homma T, Shimada Y, Tsuda H, Aiko S, Imoto I, Inazawa J, Chida K, Kamei Y, Kozuma S, Taketani Y, Matsuzawa A, Ichijo H (2009) ASK1 and ASK2 differentially regulate the counteracting roles of apoptosis and inflammation in tumorigenesis. The EMBO journal 28 (7):843-853. doi:10.1038/emboj.2009.32 [PubMed: 19214184]

Isinger-Ekstrand A, Johansson J, Ohlsson M, Francis P, Staaf J, Jonsson M, Borg A, Nilbert M (2010) Genetic profiles of gastroesophageal cancer: combined analysis using expression array and tiling array--comparative genomic hybridization. Cancer genetics and cytogenetics 200 (2):120-126. doi:10.1016/j.cancergencyto.2010.03.013 [PubMed: 20620594]

Jiang R, Scott RS, Hutt-Fletcher LM (2006) Epstein-Barr virus shed in saliva is high in B-cell-tropic glycoprotein gp42. Journal of virology 80 (14):7281-7283. doi:10.1128/JVI.00497-06 [PubMed: 16809335]

Jiang X, Hao HX, Growney JD, Woolfenden S, Bottiglio C, Ng N, Lu B, Hsieh MH, Bagdasarian L, Meyer R, Smith TR, Avello M, Charlat O, Xie Y, Porter JA, Pan S, Liu J, McLaughlin ME, Cong F (2013) Inactivating mutations of RNF43 confer Wnt dependency in pancreatic ductal adenocarcinoma. Proceedings of the National Academy of Sciences of the United States of America 110 (31):12649-12654. doi:10.1073/pnas.1307218110 [PubMed: 23847203]

Jung EJ, Jung EJ, Min SY, Kim MA, Kim WH (2012) Fibroblast growth factor receptor 2 gene amplification status and its clinicopathologic significance in gastric carcinoma. Human pathology 43 (10):1559-1566. doi:10.1016/j.humpath.2011.12.002 [PubMed: 22440694]

Kakiuchi M, Nishizawa T, Ueda H, Gotoh K, Tanaka A, Hayashi A, Yamamoto S, Tatsuno K, Katoh H, Watanabe Y, Ichimura T, Ushiku T, Funahashi S, Tateishi K, Wada I, Shimizu N, Nomura S, Koike K, Seto Y, Fukayama M, Aburatani H, Ishikawa S (2014) Recurrent gain-offunction mutations of RHOA in diffuse-type gastric carcinoma. Nature genetics 46 (6):583-587. doi:10.1038/ng.2984 [PubMed: 24816255]

Kamangar F, Dawsey SM, Blaser MJ, Perez-Perez GI, Pietinen P, Newschaffer CJ, Abnet CC, Albanes D, Virtamo J, Taylor PR (2006) Opposing risks of gastric cardia and noncardia gastric adenocarcinomas associated with Helicobacter pylori seropositivity. J Natl Cancer Inst 98 (20):1445-1452. doi:10.1093/jnci/djj393 [PubMed: 17047193]

Kim HP, Cho GA, Han SW, Shin JY, Jeong EG, Song SH, Lee WC, Lee KH, Bang D, Seo JS, Kim JI (2014a) Novel fusion transcripts in human gastric cancer revealed by transcriptome analysis. Oncogene 33 (47):5434-5441. doi:10.1038/onc.2013.490 [PubMed: 24240688]

Kim J, Fox C, Peng S, Pusung M, Pectasides E, Matthee E, Hong YS, Do IG, Jang J, Thorner AR, Van Hummelen P, Rustgi AK, Wong KK, Zhou Z, Tang P, Kim KM, Lee J, Bass AJ (2014b) Preexisting oncogenic events impact trastuzumab sensitivity in ERBB2-amplified gastroesophageal adenocarcinoma. The Journal of clinical investigation 124 (12):5145-5158. doi:10.1172/jci75200 [PubMed: 25401468]

Kozma L, Kiss I, Hajdu J, Szentkereszty Z, Szakall S, Ember I (2001) C-myc amplification and cluster analysis in human gastric carcinoma. Anticancer research 21 (1b):707-710 [PubMed: 11299830]

Lauren P (1965) The Two Histological Main Types of Gastric Carcinoma: Diffuse and So-Called Intestinal-Type Carcinoma. An Attempt at a Histo-Clinical Classification. Acta Pathol Microbiol Scand 64:31-49 [PubMed: 14320675] 
Lauwers GY, Carneiro F, Graham DY, Curado MP, Franceschi S, Montgomery E, Tatematsu M, Hattori T (2010) Gastric Carcinoma. In: WHO Classification of Tumours of the Digestive System, Fouth Edition. Bosman FT, Carneiro F, Hruban RH, Theise ND (Eds), IARC Press: Lyon. pg 48-58.

Lee J, Lee SE, Kang SY, Do IG, Lee S, Ha SY, Cho J, Kang WK, Jang J, Ou SH, Kim KM (2013) Identification of ROS1 rearrangement in gastric adenocarcinoma. Cancer 119 (9):1627-1635. doi:10.1002/cncr.27967 [PubMed: 23400546]

Lee JH, Kim SH, Han SH, An JS, Lee ES, Kim YS (2009) Clinicopathological and molecular characteristics of Epstein-Barr virus-associated gastric carcinoma: a meta-analysis. Journal of gastroenterology and hepatology 24 (3):354-365. doi:10.1111/j.1440-1746.2009.05775.x [PubMed: 19335785]

Lee JH, Park SJ, Abraham SC, Seo JS, Nam JH, Choi C, Juhng SW, Rashid A, Hamilton SR, Wu TT (2004) Frequent $\mathrm{CpG}$ island methylation in precursor lesions and early gastric adenocarcinomas. Oncogene 23 (26):4646-4654. doi:10.1038/sj.onc.1207588 [PubMed: 15064707]

Lee JL, Streuli CH (2014) Integrins and epithelial cell polarity. Journal of cell science 127 (Pt 15):3217-3225. doi:10.1242/jcs.146142 [PubMed: 24994933]

Lei Z, Tan IB, Das K, Deng N, Zouridis H, Pattison S, Chua C, Feng Z, Guan YK, Ooi CH, Ivanova T, Zhang S, Lee M, Wu J, Ngo A, Manesh S, Tan E, Teh BT, Yan So JB, Goh LK, Boussioutas A, Hon Lim TK, Flotow H, Tan P, Rozen SG (2013) Identification of Molecular Subtypes of Gastric Cancer with Different Responses to PI3-Kinase Inhibitors and 5-Fluorouracil. Gastroenterology. doi:10.1053/j.gastro.2013.05.010

Leite M, Corso G, Sousa S, Milanezi F, Afonso LP, Henrique R, Soares JM, Castedo S, Carneiro F, Roviello F, Oliveira C, Seruca R (2011) MSI phenotype and MMR alterations in familial and sporadic gastric cancer. International journal of cancer Journal international du cancer 128 (7):1606-1613. doi:10.1002/ijc.25495 [PubMed: 20533283]

Lemoine NR, Jain S, Silvestre F, Lopes C, Hughes CM, McLelland E, Gullick WJ, Filipe MI (1991) Amplification and overexpression of the EGF receptor and c-erbB-2 proto-oncogenes in human stomach cancer. Br J Cancer 64 (1):79-83. doi:10.1038/bjc.1991.243 [PubMed: 1677259]

Lengauer C, Kinzler KW, Vogelstein B (1998) Genetic instabilities in human cancers. Nature 396 (6712):643-649. doi:10.1038/25292 [PubMed: 9872311]

Leung SY, Yuen ST, Chung LP, Chu KM, Chan AS, Ho JC (1999) hMLH1 promoter methylation and lack of hMLH1 expression in sporadic gastric carcinomas with high-frequency microsatellite instability. Cancer Res 59 (1):159-164 [PubMed: 9892201]

Levine PH, Stemmermann G, Lennette ET, Hildesheim A, Shibata D, Nomura A (1995) Elevated antibody titers to Epstein-Barr virus prior to the diagnosis of Epstein-Barr-virus-associated gastric adenocarcinoma. International journal of cancer Journal international du cancer 60 (5):642-644. doi: 10.1002/ijc.2910600513 [PubMed: 7860138]

Li GM (2008) Mechanisms and functions of DNA mismatch repair. Cell research 18 (1):85-98. doi:10.1038/cr.2007.115 [PubMed: 18157157]

Li J, Woods SL, Healey S, Beesley J, Chen X, Lee JS, Sivakumaran H, Wayte N, Nones K, Waterfall JJ, Pearson J, Patch AM, Senz J, Ferreira MA, Kaurah P, Mackenzie R, Heravi-Moussavi A, Hansford S, Lannagan TR, Spurdle AB, Simpson PT, da Silva L, Lakhani SR, Clouston AD, Bettington M, Grimpen F, Busuttil RA, Di Costanzo N, Boussioutas A, Jeanjean M, Chong G, Fabre A, Olschwang S, Faulkner GJ, Bellos E, Coin L, Rioux K, Bathe OF, Wen X, Martin HC, Neklason DW, Davis SR, Walker RL, Calzone KA, Avital I, Heller T, Koh C, Pineda M, Rudloff U, Quezado M, Pichurin PN, Hulick PJ, Weissman SM, Newlin A, Rubinstein WS, Sampson JE, Hamman K, Goldgar D, Poplawski N, Phillips K, Schofield L, Armstrong J, Kiraly-Borri C, Suthers GK, Huntsman DG, Foulkes WD, Carneiro F, Lindor NM, Edwards SL, French JD, Waddell N, Meltzer PS, Worthley DL, Schrader KA, Chenevix-Trench G (2016) Point Mutations in Exon 1B of APC Reveal Gastric Adenocarcinoma and Proximal Polyposis of the Stomach as a Familial Adenomatous Polyposis Variant. American journal of human genetics 98 (5):830-842. doi:10.1016/j.ajhg.2016.03.001 [PubMed: 27087319]

Li Q, Spriggs MK, Kovats S, Turk SM, Comeau MR, Nepom B, Hutt-Fletcher LM (1997) EpsteinBarr virus uses HLA class II as a cofactor for infection of B lymphocytes. Journal of virology 71 (6):4657-4662 [PubMed: 9151859] 
Liu J, McCleland M, Stawiski EW, Gnad F, Mayba O, Haverty PM, Durinck S, Chen YJ, Klijn C, Jhunjhunwala S, Lawrence M, Liu H, Wan Y, Chopra V, Yaylaoglu MB, Yuan W, Ha C, Gilbert HN, Reeder J, Pau G, Stinson J, Stern HM, Manning G, Wu TD, Neve RM, de Sauvage FJ, Modrusan Z, Seshagiri S, Firestein R, Zhang Z (2014) Integrated exome and transcriptome sequencing reveals ZAK isoform usage in gastric cancer. Nature communications 5:3830. doi:10.1038/ncomms4830

Lo SS, Wu CW, Hsieh MC, Kuo HS, Lui WY, P'Eng FK (1996) Relationship between age and clinical characteristics of patients with gastric cancer. Journal of gastroenterology and hepatology 11 (6):511-514. doi: 10.1111/j.1440-1746.1996.tb01693.x [PubMed: 8792301]

Majewski IJ, Kluijt I, Cats A, Scerri TS, de Jong D, Kluin RJ, Hansford S, Hogervorst FB, Bosma AJ, Hofland I, Winter M, Huntsman D, Jonkers J, Bahlo M, Bernards R (2013) An alpha-E-catenin (CTNNA1) mutation in hereditary diffuse gastric cancer. The Journal of pathology 229 (4):621629. doi:10.1002/path.4152 [PubMed: 23208944]

Manninen A (2015) Epithelial polarity--generating and integrating signals from the ECM with integrins. Experimental cell research 334 (2):337-349. doi:10.1016/j.yexcr.2015.01.003 [PubMed: 25597426]

Ming SC (1977) Gastric carcinoma. A pathobiological classification. Cancer 39 (6):2475-2485. doi: 10.1002/1097-0142(197706)39:6 [PubMed: 872047]

Moarii M, Reyal F, Vert JP (2015) Integrative DNA methylation and gene expression analysis to assess the universality of the $\mathrm{CpG}$ island methylator phenotype. Human genomics 9:26. doi:10.1186/ s40246-015-0048-9 [PubMed: 26463173]

Murphy G, Pfeiffer R, Camargo MC, Rabkin CS (2009) Meta-analysis shows that prevalence of Epstein-Barr virus-positive gastric cancer differs based on sex and anatomic location. Gastroenterology 137 (3):824-833. doi:10.1053/j.gastro.2009.05.001 [PubMed: 19445939]

Nagarajan N, Bertrand D, Hillmer AM, Zang ZJ, Yao F, Jacques PE, Teo AS, Cutcutache I, Zhang Z, Lee WH, Sia YY, Gao S, Ariyaratne PN, Ho A, Woo XY, Veeravali L, Ong CK, Deng N, Desai KV, Khor CC, Hibberd ML, Shahab A, Rao J, Wu M, Teh M, Zhu F, Chin SY, Pang B, So JB, Bourque G, Soong R, Sung WK, Tean Teh B, Rozen S, Ruan X, Yeoh KG, Tan PB, Ruan Y (2012) Whole-genome reconstruction and mutational signatures in gastric cancer. Genome biology 13 (12):R115. doi:10.1186/gb-2012-13-12-r115 [PubMed: 23237666]

Nemerow GR, Mold C, Schwend VK, Tollefson V, Cooper NR (1987) Identification of gp350 as the viral glycoprotein mediating attachment of Epstein-Barr virus (EBV) to the EBV/C3d receptor of B cells: sequence homology of gp350 and C 3 complement fragment C3d. Journal of virology 61 (5):1416-1420 [PubMed: 3033269]

Oliveira C, Pinheiro H, Figueiredo J, Seruca R, Carneiro F (2015) Familial gastric cancer: genetic susceptibility, pathology, and implications for management. The Lancet Oncology 16 (2):e60-70. doi:10.1016/s1470-2045(14)71016-2 [PubMed: 25638682]

Ottini L, Falchetti M, Lupi R, Rizzolo P, Agnese V, Colucci G, Bazan V, Russo A (2006) Patterns of genomic instability in gastric cancer: clinical implications and perspectives. Annals of oncology : official journal of the European Society for Medical Oncology / ESMO 17 Suppl 7:vii97-102. doi:10.1093/annonc/mdl960

Palanisamy N, Ateeq B, Kalyana-Sundaram S, Pflueger D, Ramnarayanan K, Shankar S, Han B, Cao Q, Cao X, Suleman K, Kumar-Sinha C, Dhanasekaran SM, Chen YB, Esgueva R, Banerjee S, LaFargue CJ, Siddiqui J, Demichelis F, Moeller P, Bismar TA, Kuefer R, Fullen DR, Johnson TM, Greenson JK, Giordano TJ, Tan P, Tomlins SA, Varambally S, Rubin MA, Maher CA, Chinnaiyan AM (2010) Rearrangements of the RAF kinase pathway in prostate cancer, gastric cancer and melanoma. Nature medicine 16 (7):793-798. doi:10.1038/nm.2166

Palli D, Masala G, Del Giudice G, Plebani M, Basso D, Berti D, Numans ME, Ceroti M, Peeters PH, Bueno de Mesquita HB, Buchner FL, Clavel-Chapelon F, Boutron-Ruault MC, Krogh V, Saieva C, Vineis P, Panico S, Tumino R, Nyren O, Siman H, Berglund G, Hallmans G, Sanchez MJ, Larranaga N, Barricarte A, Navarro C, Quiros JR, Key T, Allen N, Bingham S, Khaw KT, Boeing H, Weikert C, Linseisen J, Nagel G, Overvad K, Thomsen RW, Tjonneland A, Olsen A, Trichoupoulou A, Trichopoulos D, Arvaniti A, Pera G, Kaaks R, Jenab M, Ferrari P, Nesi G, Carneiro F, Riboli E, Gonzalez CA (2007) CagA+ Helicobacter pylori infection and gastric cancer 
risk in the EPIC-EURGAST study. International journal of cancer Journal international du cancer 120 (4):859-867. doi:10.1002/ijc.22435 [PubMed: 17131317]

Palser AL, Grayson NE, White RE, Corton C, Correia S, Ba Abdullah MM, Watson SJ, Cotten M, Arrand JR, Murray PG, Allday MJ, Rickinson AB, Young LS, Farrell PJ, Kellam P (2015) Genome diversity of Epstein-Barr virus from multiple tumor types and normal infection. Journal of virology 89 (10):5222-5237. doi:10.1128/JVI.03614-14 [PubMed: 25787276]

Peleteiro B, Lopes C, Figueiredo C, Lunet N (2011) Salt intake and gastric cancer risk according to Helicobacter pylori infection, smoking, tumour site and histological type. Br J Cancer 104 (1):198-207. doi:10.1038/sj.bjc.6605993 [PubMed: 21081930]

Peltomaki P (2012) Mutations and epimutations in the origin of cancer. Experimental cell research 318 (4):299-310. doi:10.1016/j.yexcr.2011.12.001 [PubMed: 22182599]

Persson C, Canedo P, Machado JC, El-Omar EM, Forman D (2011) Polymorphisms in inflammatory response genes and their association with gastric cancer: A HuGE systematic review and metaanalyses. American journal of epidemiology 173 (3):259-270. doi:10.1093/aje/kwq370 [PubMed: 21178102]

Pinto M, Oliveira C, Machado JC, Cirnes L, Tavares J, Carneiro F, Hamelin R, Hofstra R, Seruca R, Sobrinho-Simoes M (2000) MSI-L gastric carcinomas share the hMLH1 methylation status of MSI-H carcinomas but not their clinicopathological profile. Laboratory investigation; a journal of technical methods and pathology 80 (12):1915-1923 [PubMed: 11140703]

Plummer M, Franceschi S, Vignat J, Forman D, de Martel C (2015) Global burden of gastric cancer attributable to Helicobacter pylori. International journal of cancer Journal international du cancer 136 (2):487-490. doi:10.1002/ijc.28999 [PubMed: 24889903]

Qian J, Kong X, Deng N, Tan P, Chen H, Wang J, Li Z, Hu Y, Zou W, Xu J, Fang JY (2015) OCT1 is a determinant of synbindin-related ERK signalling with independent prognostic significance in gastric cancer. Gut 64 (1):37-48. doi:10.1136/gutjnl-2013-306584 [PubMed: 24717932]

Qu Y, Dang S, Hou P (2013) Gene methylation in gastric cancer. Clinica chimica acta; international journal of clinical chemistry 424:53-65. doi:10.1016/j.cca.2013.05.002 [PubMed: 23669186]

Ryan JL, Shen YJ, Morgan DR, Thorne LB, Kenney SC, Dominguez RL, Gulley ML (2012) EpsteinBarr virus infection is common in inflamed gastrointestinal mucosa. Digestive diseases and sciences 57 (7):1887-1898. doi:10.1007/s10620-012-2116-5 [PubMed: 22410851]

Sakakura C, Mori T, Sakabe T, Ariyama Y, Shinomiya T, Date K, Hagiwara A, Yamaguchi T, Takahashi T, Nakamura Y, Abe T, Inazawa J (1999) Gains, losses, and amplifications of genomic materials in primary gastric cancers analyzed by comparative genomic hybridization. Genes, chromosomes \& cancer 24 (4):299-305. doi: 10.1002/(SICI)1098-2264(199904)24:4 [PubMed: 10092127]

Satoh T, Xu RH, Chung HC, Sun GP, Doi T, Xu JM, Tsuji A, Omuro Y, Li J, Wang JW, Miwa H, Qin SK, Chung IJ, Yeh KH, Feng JF, Mukaiyama A, Kobayashi M, Ohtsu A, Bang YJ (2014) Lapatinib plus paclitaxel versus paclitaxel alone in the second-line treatment of HER2-amplified advanced gastric cancer in Asian populations: TyTAN--a randomized, phase III study. Journal of clinical oncology : official journal of the American Society of Clinical Oncology 32 (19):20392049. doi:10.1200/jco.2013.53.6136 [PubMed: 24868024]

Schetter AJ, You WC, Lennette ET, Gail MT, Rabkin CS (2008) Association of Epstein-Barr virus antibody levels with precancerous gastric lesions in a high-risk cohort. Cancer science 99 (2):350-354. doi:10.1111/j.1349-7006.2007.00668.x [PubMed: 18201267]

Schuetz JM, Leach S, Kaurah P, Jeyes J, Butterfield Y, Huntsman D, Brooks-Wilson AR (2012) Catenin family genes are not commonly mutated in hereditary diffuse gastric cancer. Cancer epidemiology, biomarkers \& prevention : a publication of the American Association for Cancer Research, cosponsored by the American Society of Preventive Oncology 21 (12):2272-2274. doi:10.1158/1055-9965.EPI-12-1110

Shannon-Lowe C, Rowe M (2011) Epstein-Barr virus infection of polarized epithelial cells via the basolateral surface by memory B cell-mediated transfer infection. PLoS pathogens 7 (5):e1001338. doi:10.1371/journal.ppat.1001338 [PubMed: 21573183]

Shannon-Lowe CD, Neuhierl B, Baldwin G, Rickinson AB, Delecluse HJ (2006) Resting B cells as a transfer vehicle for Epstein-Barr virus infection of epithelial cells. Proceedings of the National 
Academy of Sciences of the United States of America 103 (18):7065-7070. doi:10.1073/ pnas.0510512103 [PubMed: 16606841]

Shinkura R, Yamamoto N, Koriyama C, Shinmura Y, Eizuru Y, Tokunaga M (2000) Epstein-Barr virus-specific antibodies in Epstein-Barr virus-positive and -negative gastric carcinoma cases in Japan. Journal of medical virology 60 (4):411-416. doi:10.1002/(SICI)1096-9071(200004)60:4 [PubMed: 10686024]

Sixbey JW, Yao QY (1992) Immunoglobulin A-induced shift of Epstein-Barr virus tissue tropism. Science 255 (5051):1578-1580. doi:10.1126/science.1312750 [PubMed: 1312750]

Strong MJ, Laskow T, Nakhoul H, Blanchard E, Liu Y, Wang X, Baddoo M, Lin Z, Yin Q, Flemington EK (2015) Latent Expression of the Epstein-Barr Virus (EBV)-Encoded Major Histocompatibility Complex Class I TAP Inhibitor, BNLF2a, in EBV-Positive Gastric Carcinomas. Journal of virology 89 (19):10110-10114. doi:10.1128/JVI.01110-15 [PubMed: 26178981]

Su X, Zhan P, Gavine PR, Morgan S, Womack C, Ni X, Shen D, Bang YJ, Im SA, Ho Kim W, Jung EJ, Grabsch HI, Kilgour E (2014) FGFR2 amplification has prognostic significance in gastric cancer: results from a large international multicentre study. Br J Cancer 110 (4):967-975. doi:10.1038/ bjc.2013.802 [PubMed: 24457912]

Tan IB, Ivanova T, Lim KH, Ong CW, Deng N, Lee J, Tan SH, Wu J, Lee MH, Ooi CH, Rha SY, Wong WK, Boussioutas A, Yeoh KG, So J, Yong WP, Tsuburaya A, Grabsch H, Toh HC, Rozen S, Cheong JH, Noh SH, Wan WK, Ajani JA, Lee JS, Tellez MS, Tan P (2011) Intrinsic subtypes of gastric cancer, based on gene expression pattern, predict survival and respond differently to chemotherapy. Gastroenterology 141 (2):476-485, 485.e471-411. doi:10.1053/ j.gastro.2011.04.042 [PubMed: 21684283]

Tanner J, Weis J, Fearon D, Whang Y, Kieff E (1987) Epstein-Barr virus gp350/220 binding to the B lymphocyte C3d receptor mediates adsorption, capping, and endocytosis. Cell 50 (2):203-213. doi:10.1016/0092-8674(87)90216-9 [PubMed: 3036369]

Tao J, Deng NT, Ramnarayanan K, Huang B, Oh HK, Leong SH, Lim SS, Tan IB, Ooi CH, Wu J, Lee M, Zhang S, Rha SY, Chung HC, Smoot DT, Ashktorab H, Kon OL, Cacheux V, Yap C, Palanisamy N, Tan P (2011) CD44-SLC1A2 gene fusions in gastric cancer. Science translational medicine 3 (77):77ra30. doi:10.1126/scitranslmed.3001423

Thorley-Lawson DA, Hawkins JB, Tracy SI, Shapiro M (2013) The pathogenesis of Epstein-Barr virus persistent infection. Current opinion in virology 3 (3):227-232. doi:10.1016/j.coviro.2013.04.005 [PubMed: 23683686]

Tsai MH, Raykova A, Klinke O, Bernhardt K, Gartner K, Leung CS, Geletneky K, Sertel S, Munz C, Feederle R, Delecluse HJ (2013) Spontaneous lytic replication and epitheliotropism define an Epstein-Barr virus strain found in carcinomas. Cell reports 5 (2):458-470. doi:10.1016/ j.celrep.2013.09.012 [PubMed: 24120866]

Tsugawa K, Fushida S, Yonemura Y (1993) Amplification of the c-erbB-2 gene in gastric carcinoma: correlation with survival. Oncology 50 (6):418-425. doi:10.1159/000227222 [PubMed: 7901825]

Tugizov SM, Berline JW, Palefsky JM (2003) Epstein-Barr virus infection of polarized tongue and nasopharyngeal epithelial cells. Nature medicine 9 (3):307-314. doi:10.1038/nm830

Umar A, Boland CR, Terdiman JP, Syngal S, de la Chapelle A, Ruschoff J, Fishel R, Lindor NM, Burgart LJ, Hamelin R, Hamilton SR, Hiatt RA, Jass J, Lindblom A, Lynch HT, Peltomaki P, Ramsey SD, Rodriguez-Bigas MA, Vasen HF, Hawk ET, Barrett JC, Freedman AN, Srivastava S (2004) Revised Bethesda Guidelines for hereditary nonpolyposis colorectal cancer (Lynch syndrome) and microsatellite instability. J Natl Cancer Inst 96 (4):261-268. doi: 10.1093/jnci/ djh034 [PubMed: 14970275]

Van Cutsem E, de Haas S, Kang YK, Ohtsu A, Tebbutt NC, Ming Xu J, Peng Yong W, Langer B, Delmar P, Scherer SJ, Shah MA (2012) Bevacizumab in combination with chemotherapy as first-line therapy in advanced gastric cancer: a biomarker evaluation from the AVAGAST randomized phase III trial. Journal of clinical oncology : official journal of the American Society of Clinical Oncology 30 (17):2119-2127. doi:10.1200/jco.2011.39.9824 [PubMed: 22565005]

van der Post RS, Vogelaar IP, Carneiro F, Guilford P, Huntsman D, Hoogerbrugge N, Caldas C, Schreiber KE, Hardwick RH, Ausems MG, Bardram L, Benusiglio PR, Bisseling TM, Blair V, Bleiker E, Boussioutas A, Cats A, Coit D, DeGregorio L, Figueiredo J, Ford JM, Heijkoop E, 
Hermens R, Humar B, Kaurah P, Keller G, Lai J, Ligtenberg MJ, O’Donovan M, Oliveira C, Pinheiro H, Ragunath K, Rasenberg E, Richardson S, Roviello F, Schackert H, Seruca R, Taylor A, Ter Huurne A, Tischkowitz M, Joe ST, van Dijck B, van Grieken NC, van Hillegersberg R, van Sandick JW, Vehof R, van Krieken JH, Fitzgerald RC (2015) Hereditary diffuse gastric cancer: updated clinical guidelines with an emphasis on germline CDH1 mutation carriers. Journal of medical genetics 52 (6):361-374. doi:10.1136/jmedgenet-2015-103094 [PubMed: 25979631]

Velho S, Fernandes MS, Leite M, Figueiredo C, Seruca R (2014) Causes and consequences of microsatellite instability in gastric carcinogenesis. World journal of gastroenterology 20 (44):16433-16442. doi:10.3748/wjg.v20.i44.16433 [PubMed: 25469011]

Wang HB, Zhang H, Zhang JP, Li Y, Zhao B, Feng GK, Du Y, Xiong D, Zhong Q, Liu WL, Du H, Li MZ, Huang WL, Tsao SW, Hutt-Fletcher L, Zeng YX, Kieff E, Zeng MS (2015) Neuropilin 1 is an entry factor that promotes EBV infection of nasopharyngeal epithelial cells. Nature communications 6:6240. doi:10.1038/ncomms 7240

Wang K, Kan J, Yuen ST, Shi ST, Chu KM, Law S, Chan TL, Kan Z, Chan AS, Tsui WY, Lee SP, Ho SL, Chan AK, Cheng GH, Roberts PC, Rejto PA, Gibson NW, Pocalyko DJ, Mao M, Xu J, Leung SY (2011) Exome sequencing identifies frequent mutation of ARID1A in molecular subtypes of gastric cancer. Nature genetics 43 (12):1219-1223. doi:10.1038/ng.982 [PubMed: 22037554]

Wang K, Yuen ST, Xu J, Lee SP, Yan HH, Shi ST, Siu HC, Deng S, Chu KM, Law S, Chan KH, Chan AS, Tsui WY, Ho SL, Chan AK, Man JL, Foglizzo V, Ng MK, Ching YP, Cheng GH, Xie T, Fernandez J, Li VS, Clevers H, Rejto PA, Mao M, Leung SY (2014) Whole-genome sequencing and comprehensive molecular profiling identify new driver mutations in gastric cancer. Nature genetics 46 (6):573-582. doi:10.1038/ng.2983 [PubMed: 24816253]

Wang X, Kenyon WJ, Li Q, Mullberg J, Hutt-Fletcher LM (1998) Epstein-Barr virus uses different complexes of glycoproteins gH and gL to infect B lymphocytes and epithelial cells. Journal of virology 72 (7):5552-5558 [PubMed: 9621012]

Weiss MM, Kuipers EJ, Postma C, Snijders AM, Pinkel D, Meuwissen SG, Albertson D, Meijer GA (2004) Genomic alterations in primary gastric adenocarcinomas correlate with clinicopathological characteristics and survival. Cellular oncology : the official journal of the International Society for Cellular Oncology 26 (5-6):307-317. doi: 10.1155/2004/454238 [PubMed: 15623941]

Wong SS, Kim KM, Ting JC, Yu K, Fu J, Liu S, Cristescu R, Nebozhyn M, Gong L, Yue YG, Wang J, Ronghua C, Loboda A, Hardwick J, Liu X, Dai H, Jin JG, Ye XS, Kang SY, Do IG, Park JO, Sohn TS, Reinhard C, Lee J, Kim S, Aggarwal A (2014) Genomic landscape and genetic heterogeneity in gastric adenocarcinoma revealed by whole-genome sequencing. Nature communications 5:5477. doi:10.1038/ncomms6477

Xiao J, Palefsky JM, Herrera R, Berline J, Tugizov SM (2008) The Epstein-Barr virus BMRF-2 protein facilitates virus attachment to oral epithelial cells. Virology 370 (2):430-442. doi:10.1016/ j.virol.2007.09.012 [PubMed: 17945327]

Xie L, Su X, Zhang L, Yin X, Tang L, Zhang X, Xu Y, Gao Z, Liu K, Zhou M, Gao B, Shen D, Zhang L, Ji J, Gavine PR, Zhang J, Kilgour E, Zhang X, Ji Q (2013) FGFR2 gene amplification in gastric cancer predicts sensitivity to the selective FGFR inhibitor AZD4547. Clinical cancer research : an official journal of the American Association for Cancer Research 19 (9):2572-2583. doi:10.1158/1078-0432.ccr-12-3898 [PubMed: 23493349]

Yamamoto H, Perez-Piteira J, Yoshida T, Terada M, Itoh F, Imai K, Perucho M (1999) Gastric cancers of the microsatellite mutator phenotype display characteristic genetic and clinical features. Gastroenterology 116 (6):1348-1357. doi:10.1016/S0016-5085(99)70499-3 [PubMed: 10348818]

Yao F, Kausalya JP, Sia YY, Teo AS, Lee WH, Ong AG, Zhang Z, Tan JH, Li G, Bertrand D, Liu X, Poh HM, Guan P, Zhu F, Pathiraja TN, Ariyaratne PN, Rao J, Woo XY, Cai S, Mulawadi FH, Poh WT, Veeravalli L, Chan CS, Lim SS, Leong ST, Neo SC, Choi PS, Chew EG, Nagarajan N, Jacques PE, So JB, Ruan X, Yeoh KG, Tan P, Sung WK, Hunziker W, Ruan Y, Hillmer AM (2015) Recurrent Fusion Genes in Gastric Cancer: CLDN18-ARHGAP26 Induces Loss 
of Epithelial Integrity. Cell reports 12 (2):272-285. doi:10.1016/j.celrep.2015.06.020 [PubMed: 26146084]

Zang ZJ, Cutcutache I, Poon SL, Zhang SL, McPherson JR, Tao J, Rajasegaran V, Heng HL, Deng N, Gan A, Lim KH, Ong CK, Huang D, Chin SY, Tan IB, Ng CC, Yu W, Wu Y, Lee M, Wu J, Poh D, Wan WK, Rha SY, So J, Salto-Tellez M, Yeoh KG, Wong WK, Zhu YJ, Futreal PA, Pang B, Ruan Y, Hillmer AM, Bertrand D, Nagarajan N, Rozen S, Teh BT, Tan P (2012) Exome sequencing of gastric adenocarcinoma identifies recurrent somatic mutations in cell adhesion and chromatin remodeling genes. Nature genetics 44 (5):570-574. doi:10.1038/ng.2246 [PubMed: 22484628]

Zang ZJ, Ong CK, Cutcutache I, Yu W, Zhang SL, Huang D, Ler LD, Dykema K, Gan A, Tao J, Lim S, Liu Y, Futreal PA, Grabsch H, Furge KA, Goh LK, Rozen S, Teh BT, Tan P (2011) Genetic and structural variation in the gastric cancer kinome revealed through targeted deep sequencing. Cancer Res 71 (1):29-39. doi:10.1158/0008-5472.CAN-10-1749 [PubMed: 21097718]

Zhu L, Li Z, Wang Y, Zhang C, Liu Y, Qu X (2015) Microsatellite instability and survival in gastric cancer: A systematic review and meta-analysis. Molecular and clinical oncology 3 (3):699-705. doi:10.3892/mco.2015.506 [PubMed: 26137290]

Zouridis H, Deng N, Ivanova T, Zhu Y, Wong B, Huang D, Wu YH, Wu Y, Tan IB, Liem N, Gopalakrishnan V, Luo Q, Wu J, Lee M, Yong WP, Goh LK, Teh BT, Rozen S, Tan P (2012) Methylation subtypes and large-scale epigenetic alterations in gastric cancer. Science translational medicine 4 (156):156ra140. doi:10.1126/scitranslmed.3004504 


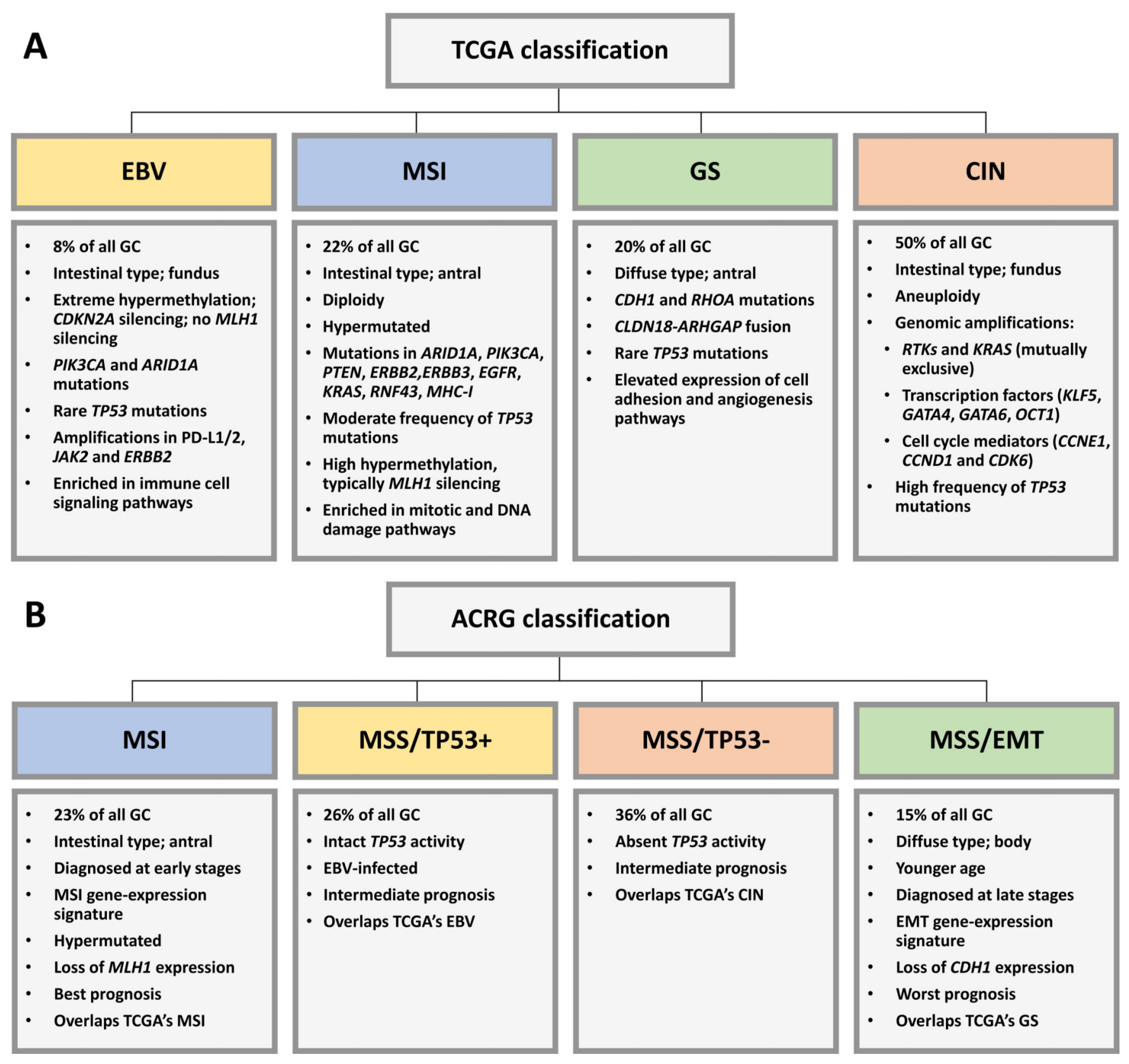

Fig. 12.1.

Current gastric cancer classifications based on comprehensive molecular analyses. The main features of each subtype are highlighted in the boxes below each subtype. (A) TCGA classification (Cancer Genome Atlas Research 2014). (B) ACRG classification (Cristescu et al. 2015). 